\title{
Analysis of material flow and consumption in cement production process
}

\author{
Tianming Gao a, b, Lei Shen ${ }^{\text {a, **, }}{ }^{\text {, Ming Shen }}{ }^{\text {a, b, *, Litao Liu }}{ }^{\text {a }}$, Fengnan Chen ${ }^{\text {a, b }}$ \\ a Institute of Geographic Sciences and Natural Resources Research (IGSNRR), CAS, 11A Datun Road, Chaoyang District, Beijing 100101, PR China \\ ${ }^{\mathrm{b}}$ University of Chinese Academy of Sciences, Beijing 100049, PR China
}

\section{A R T I C L E I N F O}

\section{Article history:}

Received 4 February 2015

Received in revised form

13 August 2015

Accepted 13 August 2015

Available online 21 August 2015

\section{Keywords:}

Material flow

Material efficiency

Mass balance

Cement production

China

\begin{abstract}
A B S T R A C T
Cement production, which is highly dependent on the availability of natural resources, will face severe resource constraints in the future. This is especially true for the cement industry in China. Thus, the industry is focusing on reducing the consumption of natural resources at both the manufacturing and operational stages. The aim of this article is to improve the management of resources used in the cement production process and mitigate their environmental effects. First, material flow routes for the cement manufacturing process are established, after which three mass balances are built during the three production stages using actual plant data received from an existing cement manufacturing facility. Finally, the material efficiency of the units and stages as well as the waste recycle rates during these stages is calculated. The results show that approximately $2.48 \mathrm{t}, 4.69 \mathrm{t}$, and $3.41 \mathrm{t}$ of materials are required to produce a ton of the product in raw material preparation, clinker production, and cement grinding stages, and their waste rates are $63.31 \%, 74.12 \%$, and $78.89 \%$, respectively. The recycling rate of wastes during clinker production is remarkably higher than those during other manufacturing stages, wherein waste gases are directly discharged into the atmosphere. The material efficiency values for a raw mill, pyro-processing tower, rotary kiln, clink cooler, and cement mill are determined to be $36.69 \%$, $34.24 \%, 39.24 \%, 29.76 \%$, and $25.88 \%$, respectively, whereas the waste recycling rates for these units are found to be $16.33 \%, 81.98 \%, 100.00 \%, 99.53 \%$, and $0.00 \%$ respectively. These results will provide researchers with knowledge regarding the effectiveness and efficient use of natural resources in the cement sector. These important findings can also be used to influence the development of national and industrial policies in relation to the goal of achieving sustainable development in the cement industry. Crown Copyright $\odot 2015$ Published by Elsevier Ltd. All rights reserved.
\end{abstract}

\section{Introduction}

Over the last century, Portland cement-based concrete has become the highest manufactured product on Earth in terms of volume. Concrete is used worldwide as a building material and is the most consumed substance on Earth after water (Sakai, 2009). The volume of concrete produced globally is approximately 5.30 billion $\mathrm{m}^{3}$ per year (Roskos et al., 2011), with more than 12.00 billion tons (Bt) of material used annually. Cement is an essential binding agent in concrete and is key material for satisfying

\footnotetext{
* Corresponding author. Institute of Geographic Sciences and Natural Resources Research (IGSNRR), CAS, 11A Datun Road, Chaoyang District, Beijing 100101, PR China. Tel.: +861064888073 13; fax: +861064889005.

** Corresponding author. Tel.: +86 1064888073 13; fax: +86 1064889005 .

E-mail addresses: shenl@igsnrr.ac.cn (L. Shen), gaoming0920@aliyun.com (M. Shen).

global housing and modern infrastructure needs. In 2011, the world cement production was approximately $3.60 \mathrm{Bt} / 3.30 \mathrm{Bt}$ (clinker) (U.S.G.S., U.S.Geological Survey. 2014), requiring more than $3.00 \mathrm{Bt}$ of limestone for the manufacture of clinker (Schneider et al., 2011). However, large material flows solely related to cement production have a significant impact on society and the environment. Cement production has some adverse effects, from large-scale emissions of greenhouse gas and particulate matter to massive consumption of natural resources such as limestone, clay, and sand. Therefore, the cement industry is being faced with several issues that need to be resolved, including the rising costs in energy supply, the requirement to reduce emissions linked to global warming, and the insufficient availability of high-quality raw materials.

The need for a sustainable tradeoff between cement production and natural resource consumption is an increasing global issue. Natural material deposits are limited, and hence, they will not be able to supplement the large-scale production and consumption of 
cement. Raw materials for clinker production are, for good reasons, primarily based on limestone, clay, or its natural mixture, marl. The production of a ton of Portland cement requires 1.50 t of raw materials (Elchalakani et al., 2014). This means that approximately $5.40 \mathrm{Bt}$ of raw materials were consumed globally for cement production in 2011, whereas the ratio of the amount of raw materials to per ton of clinker is usually $1.50 \mathrm{t}-1.69 \mathrm{t}$ in China, according to cement engineering experience ( $\mathrm{Li}$ et al., 2014a). The potential shortage of raw materials in the future, particularly the fate of the material, should primarily be considered in the cement industry because of the high consumption of conventional limestone-based resources. China is the world's leading producer of cement: its cement production was 2.08 Bt in 2011 (NBSC, National Bureau of Statistics of China, 2012), accounting for $57.78 \%$ of the world's total production. Considering the future growth of cement production in China, limestone deposits will be depleted in 59 years (other uses of limestone deposits in the industry are not taken into account) (Karstensen, 2006). However, according to current cement output, China's cement industry will face severe resource constraints by 2030 (Gao, 2013). Thus, the efficient usage of existing limited resources and the construction of an environmental friendly cement industry have gained importance.

The development of sustainable construction and building materials with reduced consumption of natural resources in both the manufacturing and operational phases is currently a key focus in the global cement industry. Research on material flow, energy flow, and the relationship between them will benefit the construction of a resource-saving and environmentally friendly cement industry. Recently, more researchers have been focusing on material and energy flows in industries or enterprises. Brown (1996) initially created material and energy flow models for 108 different manufacturing processes. Based on this study, certain researchers attempted to separate the energy consumption in an industrial process into stages.

Many studies have focused on material and energy flows in the chemical (Worrell et al., 2000), petroleum (Ozalp and Hyman, 2007; Wang et al., 2004), metal (Andersen and Hyman, 2001; Michaelis and Jackson, 2000), and paper manufacturing industry (Hong et al., 2011); they have mainly focused on increasing the energy and material efficiency in these industries, and only a few scholars have been concerned with the cement/concrete industry. Low (2005) performed the first comprehensive material flow analysis for concrete, and calculated the amounts of raw material, water, and energy required as input, as well as the amounts of cement, emissions, cement clinker dust, and water required as output in US cement production. Kapur et al. (2009) developed a country-level stock and flow model for cement. Smith et al. (2002) established the mass balance of the UK construction industry and quantified natural resources, wastes, and emissions. The material life cycle of concrete was analyzed by Woodward and Duffy (2011). With respect to environmental implications, Uwasu et al. (2014) argued that it is of critical importance to control excessive cement demand. Gao et al. (2014) found that replacing carbonatecontaining materials with non-carbonate materials and changing the clinker ratio are primary solutions for reducing natural resource consumption and process emissions. Over the years, the recycling of waste, such as building material waste (Oh et al., 2014), steel slag (Iacobescu et al., 2011), sugar filter mud (Li et al., 2014b), sewage sludge ash (Baeza-Brotons et al., 2014), tire rubber (Shu and Huang, 2014), into cement production has been generating increasing interest. The key strength of prior efforts was to identify the materials used, energy consumed, and emissions produced; effort was also made to determine alternative resources and waste for recycling. However, there is no direct linkage between the input and output. Substance flow analysis only covers a very narrow range of material flow in this system; therefore, it is limited to providing information for overall resource management and determining the effects of substitution by other substances.

It is widely accepted that improving the management of material used in cement consumption is highly critical in China owing to the sheer volume of cement produced annually and the associated resource and environmental impact (Chen et al., 2014; Gao, 2013). Studies on mass flows associated with the cement manufacturing process are fairly limited, and this study intends to fill the "gap." The purpose of this study is to examine the material flow in a typical cement production process, to quantify and understand the material flows in each stage, and to identify opportunities for more effective material management. Overall, this study aims to determine any aspects in the process that can be improved, as well as the flow of substances and energy to ensure a sustainable cement industry.

\section{Material flow in cement production process}

Because the aim of the present work is to examine material flow and quantify the amount of material consumed during the cement processing stage, it is necessary to understand the cement production process and its primary machinery. The primary pieces of equipment used in cement production are electrical motors, pumps, compressors, transformers, furnaces, fans, blowers, conveyors, chillers, cooling towers, kiln, transportation systems, and lighting systems (Madlool et al., 2011). Clinker is produced by burning a mixture of materials in a cement kiln. Different kiln technologies are currently in use: new suspension pre-heater and pre-calciner kiln (NSP kiln), dry rotary kiln with pre-heater, dry long rotary kiln, semi-dry rotary kiln, semi-wet rotary kiln, wet rotary kiln, and shaft kiln (Pardo et al., 2011). By the end of 2011, there were 1637 units of NSP kilns, with a clinker production capacity of $1604 \mathrm{Mt}$ (CCA, China Cement Association. 2012). Thus, the clinker production using an NSP kiln has been the most used technology among the other kiln technologies in China. A typical NSP kiln cement production process is illustrated in supplementary material. Portland cement is generally made from calcareous and argillaceous materials, combined with smaller quantities of ironbearing materials and sand. These materials are grounded, blended, pre-calcined, and burned for manufacturing cement clinker. Thus, the production of cement involves mining; crushing, and grinding of raw materials (principally limestone and clay); calcining the materials in a rotary kiln; cooling the resulting clinker; mixing the clinker with gypsum; and milling, storing, and bagging the finished cement. Usually, the basic cement manufacturing process is divided into three production stages: raw material preparation, clinker production, and cement grinding (Supplementary material).

\subsection{Mass flows in raw material preparation}

The preparation of raw material involves primary and secondary crushing of the quarried material, drying of the material, further raw grinding, and blending of the material.

The mined limestone is fed to primary and secondary crushers where its size is reduced to $25 \mathrm{~mm}$. In recent times, a tertiary crusher has been used to further reduce the inlet size to the mill. After passing through a series of crushers and screens, the limestone is reduced to a suitable size and stored in storage systems through stacker conveyors. The flow of sandstone in this phase is similar to that of limestone (Supplementary material). Other materials such as iron, clay, quartzite, and/or silica are required to achieve the required raw feed chemical compositions. The crushed pieces are then milled together to produce "raw meal." These 


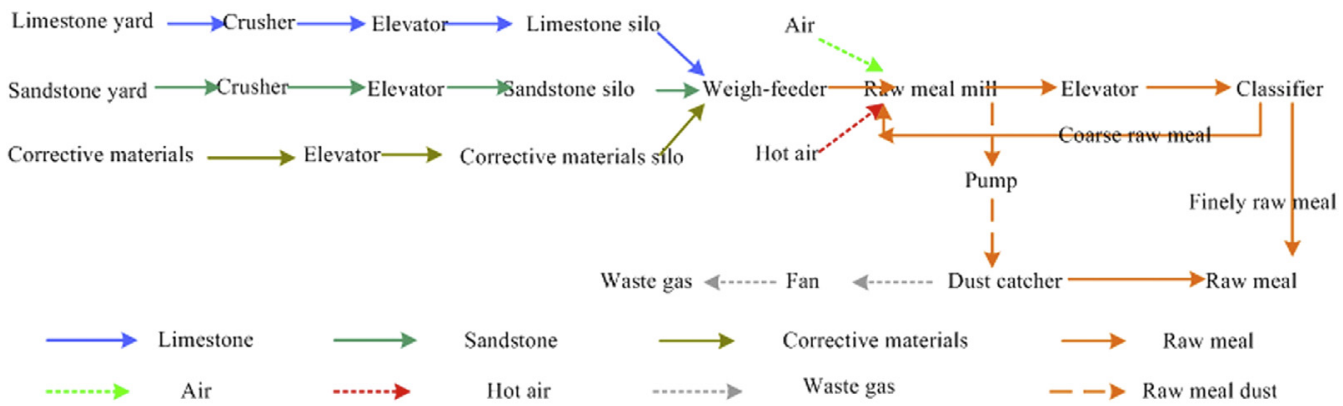

Fig. 1. Mass flows in raw meal grinding stage.

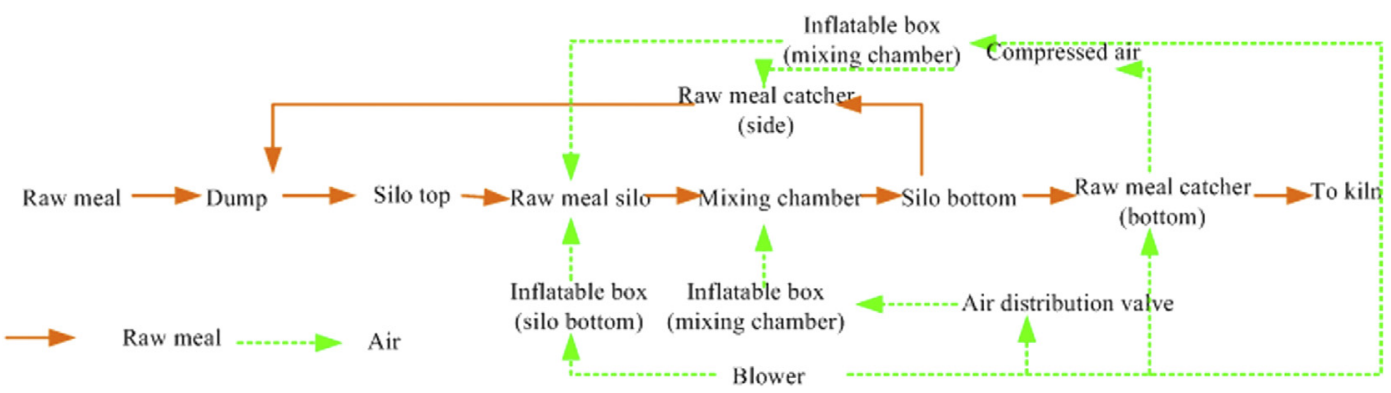

Fig. 2. Mass flows in raw meal blending and silo storage.

crushed materials are stored in feed hoppers and are fed, in the required proportions, to the raw mill by using conveyor belts in conjunction with weigh feeders. For the process of cement manufacture, it is necessary to grind the raw materials into a flowable powder before they enter the kiln. Generally, ball mills and vertical roller mills are used. The raw mix is dried by using part of the excess heat from the kiln in the process line or from a stove. The hot air and raw materials are simultaneously fed into the grinding position, dried, and ground. Then, the fresh raw meal taken from the mill is transported to a classifier, which is used to separate the finely ground particles from the coarse particles. Materials that are not suitable in size when leaving the raw mill are returned to the mill from the separator, while the fine particles are transported to a raw meal silo for blending (Fig. 1). This type of classifier is also used in coal and cement mills. A small amount of dust is generated by the precipitator and conveyed to the raw meal silo; the remaining waste gas ${ }^{1}$ is discharged by fans (Fig. 1).

Variations in the composition of raw meal adversely impact the quality of clinkers. To reduce the natural chemical variations in the various raw materials, it is necessary to efficiently blend and homogenize the raw meal. To properly blend and homogenize the raw meal, continuous blending silos are used. Raw meal homogenization is primarily completed in a closed round storehouse. Two primary blending methods are widely used: mechanical agitation and air mixing. Air mixing is generally used by large-scale companies, whereas mechanical agitation is generally adopted by small enterprises. Blending and homogenization are also performed in coal, clinker, and cement silos.

Material flow in raw meal homogenization is illustrated in Fig. 2; the raw meals are blended by the air mixing method. A blower distributes air into an inflatable box at the bottom of the silo and mixing chamber and the raw meal catcher. Raw meal from the raw

\footnotetext{
${ }^{1}$ Unless otherwise specified, waste gas is a type of mixed gas, including $\mathrm{CO}_{2}, \mathrm{~N}_{2}$, $\mathrm{CO}, \mathrm{SO}_{2}$, and $\mathrm{NO}_{\mathrm{X}}$.
}

mill is elevated to the upper end of the silo, where it contacts the swirling air moving in the opposite direction during landing, after which it is dropped into the mixing chamber. The blended raw meals overflow from the chamber into the reservoir bottom catcher, and then transported to the kiln. Part of the raw meal at the bottom of silo is conveyed to the side silo catcher, and then elevated to the upper end of the silo by a lift dump. This implies that the raw meal homogenization process will take place again.

\subsection{Mass flows in clinker production}

Fuel is combusted to produce heat for the clinker production process; coal is the traditional fuel used in China's cement industry. The raw coal from the stockyard is crushed in a hammer crusher and fed to the coal mill. The coal mill is a vertical roller mill, in which the coal particles are collected in a bag filter through a grit separator. The required size of coal is $80 \%$ of $90 \mu \mathrm{m}$ and less than $2 \%$ of $212 \mu \mathrm{m}$ (Atmaca and Yumrutaş, 2014). Hot air generated in a coal-fired furnace or from a cooler/pre-heater is used for drying the coal in the mill. The pulverized coal is homogenized in a coal silo, in preparation for calcination in a calciner system and for the meal to be melted into clinker.

Clinkering is the primary step in the cement manufacturing process. The function of the kiln in the cement industry is to first convert limestone into lime, then react it with silica, aluminum oxide, and ferric oxide to form clinker compounds: $C_{3} S, C_{2} S, C_{3} A$, and $\mathrm{C}_{4} \mathrm{AF}$. The kiln is the heart of this production process. An NSP kiln, which contains the essential pre-heater and pre-calciner system, represents advanced production technology that consumes less energy than other, outdated kilns. The pre-heater tower includes four to six multi-stage cyclones that are placed above each other in towers (Supplementary material). The latest pre-heater towers contain a combustion chamber (pre-calciner) that is linked to the pre-heater and the kiln (Supplementary material). The kiln is installed at a horizontal slope of $3-4^{\circ}$, and rotates slowly to move the raw meal toward the direction of the flame at the lower 


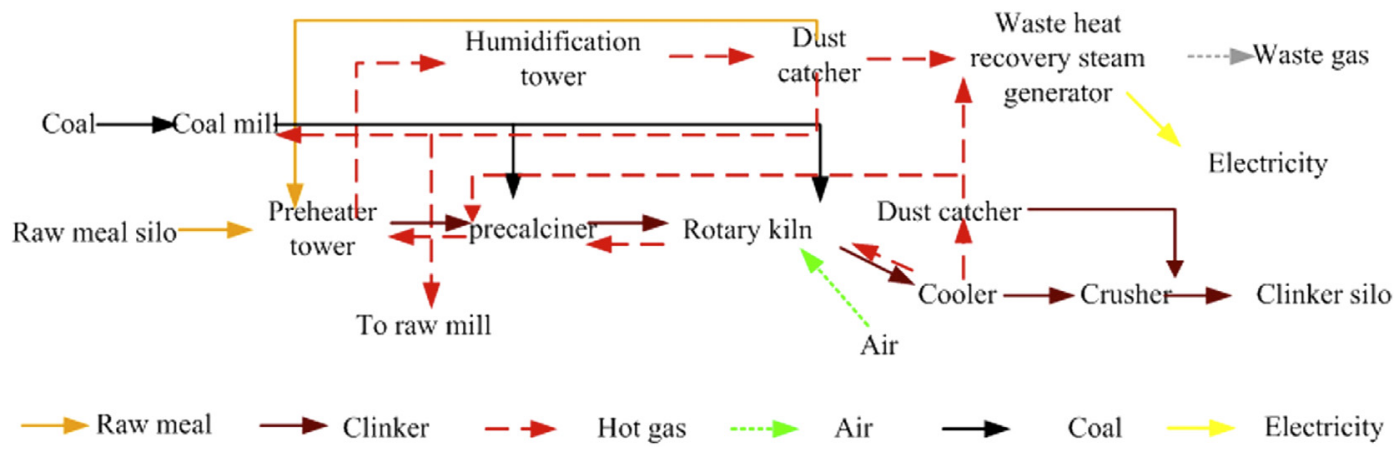

Fig. 3. Mass flow in clinker production.

end of the kiln. In hotter zones, the sequence of chemical and physical changes begins to take place, and the raw meal will be melted and fused together to form a clinker. Supplementary material shows the process of clinker production in an NSP kiln.

During the clinker production stage, raw meal is fed into the upper end of the pre-heater tower, and then passed through the end of the rotary kiln. Hot exhaust gas from the rotary kiln passes counter-currently through the downward moving raw meal in the pre-heater cyclones. The increase in temperature owing to descent of the raw meal from the top to the bottom of the tower causes the occurrence of physical processes and chemical reactions. During pre-processing, water is first evaporated, after which the chemical composition is changed. When the temperature of materials increase to $373.15 \mathrm{~K}$, uncombined water is evaporated from the raw meal. Then, the meal is dehydrated when the temperature increases to approximately $703.15 \mathrm{~K}$, and forms oxides of silicon, aluminum, and iron. At this point, the generated $\mathrm{CO}_{2}$ leaves the material, causing the raw meal to lose more than one-third of its original weight. The primary calcination (60-65\%) occurs in the pre-calciner chamber, which consumes approximately $40 \%$ of the coal used in the kiln. In the pre-heater and pre-calciner system, approximately $80-90 \%$ of the raw meal is calcined (Madlool et al., 2011) to produce $\mathrm{CO}_{2}$, which is discharged from the top of the cyclones.

The pre-calcined meal then enters the kiln, and slides and tumbles down through increasingly hotter zones, where fuel is fired directly to attain temperatures of up to $1723.15 \mathrm{~K}$. Then, a reaction takes place between calcium oxide and other elements. Approximately $60 \%$ of the coal is used to maintain a sufficiently high temperature in the burning zone to facilitate the chemical reactions. A nodular product designated as clinker is produced and allowed to leave the kiln. Ambient air is blown using an air cooler over the hot clinker. The red-hot clinker is discharged from the end of the kiln and passes through different types of coolers to partially recover its thermal energy and reach a lower clinker handling temperature $(363.15 \mathrm{~K})$. The hot air from the recuperation zone is used mainly as burning air (second dry air) and pre-calciner fuel (tertiary air) (Fig. 3). The remaining air is sent to the stack through multiple-cyclones or an electrostatic precipitator. Then the cooled clinker is transferred to a storage tank, where it is readied for the final grinding process.

The pre-heater exhaust gas and hot air from the clinker cooler discharge are the sources of waste heat. This waste heat can potentially be used for improving the energy efficiency in industrial processes. These heat sources may be used separately or together for waste heat recovery power generation. Usually, the exhaust gas discharged from the pre-heater is used within the cement plant for drying raw materials. The available waste energy from clinker cooler exhaust gas is used to generate steam. This steam can drive a steam turbine to generate electricity at the required output (Fig. 3).

\subsection{Mass flows in cement grinding}

This is the final step in the cement manufacturing process. Gypsum is blended with the ground clinker, along with other materials, to produce finished cement. Depending on the availability of additives, the cement standards, and the cement market, specific quantities, types, and compositions of additives are added to the clinker (Benhelal et al., 2013). All cement types contain approximately $4-5 \%$ gypsum to control the setting time of the product. Other mineral components such as slag, power plant fly ash, limestone, and other materials are used to replace clinker to produce blended cement. The process of cement grinding is shown in supplementary material.

Finish milling is the grinding of clinker to produce a fine gray powder. Fig 4 shows material flows during the cement grinding. Clinker, gypsum, and additives are matched in required proportions by a weigh feeder, after which they are conveyed to the mill that performs the remaining grinding. The grinding process occurs in a closed system with an air separator that divides the cement

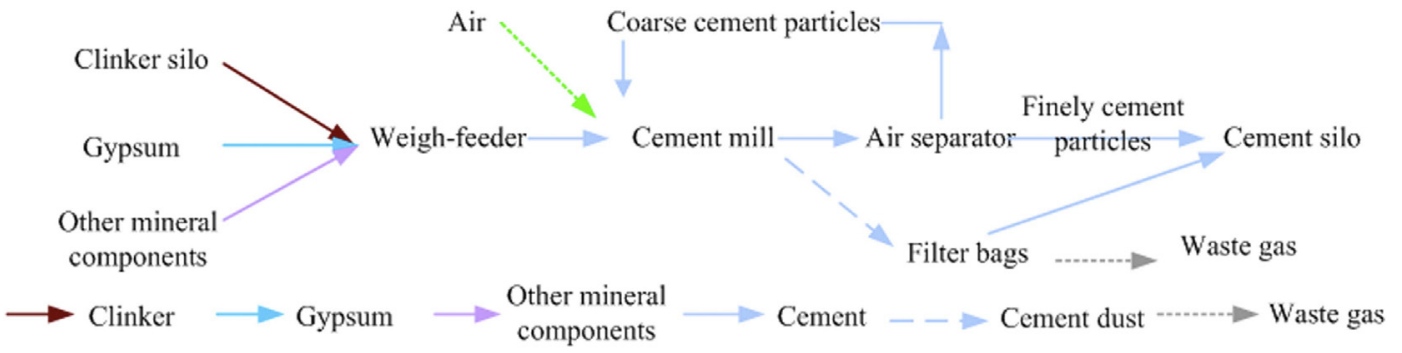

Fig. 4. Mass flows in cement grinding. 
particles according to size. The particles that have not been completely ground are resent through the mill. The fine particles are conveyed to the cement storage. The waste gas discharged from the mill is pumped to a bag filter by a vertical pneumatic pump. The produced cement dust is collected and taken to a cement silo, and the remaining waste gases are discharged to the atmosphere. The final product is homogenized and stored in a cement silo; from there, it is dispatched to either a packing station or a silo truck.

\section{Mass calculation method and boundary}

Mass flows are formed when the material runs along a cement production line. A production line is composed of three processing stages, and each stage is composed of several units (Fig. 5). In each unit's material flow structure, the flow rate and flow direction are varied. In the production process, material consumption needs to be investigated at every point, and a large number of measurements are taken. To analyze the material flow of a cement production line, the material flow model of each unit should be established.

The mass balance is expressed as follows: $\sum M_{\text {in }}=\sum M_{\text {out }}$

where the subscript "in" stands for input and "out" for output.

To analyze the units' material balance, the following assumptions are made:

1) The units within the system operate in a steady state condition and steady flow process.

2) Ideal gas principles are applied to air and combustion gas.

3) Combustion and calcination reactions are complete.

4) The ambient temperature is constant throughout the period of study.

5) Material losses during transport among units are ignored.

\subsection{Material flow models of a unit and a stage}

The material flows through a producing unit are shown in Fig. 6. Five material flows may emerge during the $j$ th unit of the $i$ th stage: those from the anterior producing unit $\left(F_{i-1}^{j}\right)$, those from the

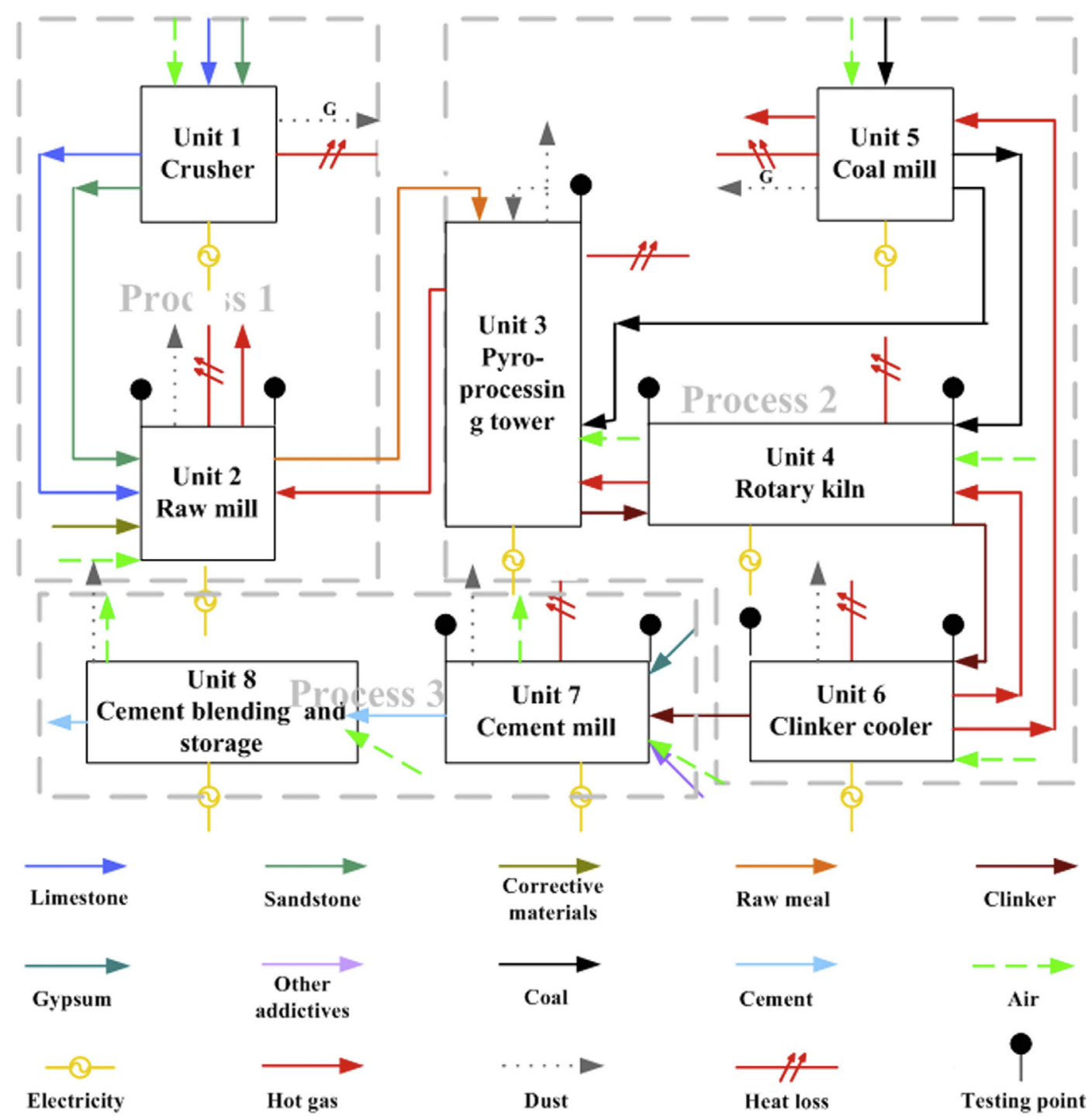

Fig. 5. Schematic of an actual cement manufacturing plant. Source: Modified from Atmaca and Yumrutaș (2014). 
environment $\left(\alpha_{i}^{j}\right)$, those to the environment $\left(\gamma_{i}^{j}\right)$, those recycled through unit $(i, j)\left(\beta_{i, i}^{j}, \beta_{i, k}^{j}, \beta_{i, m}^{j}\right)$, and those to the following production unit $\left(F_{i}^{j}\right)$. Owing to the variable flow rates at different times, the flow rates of these five material flows are assessed with respect to the average material flow rate per unit time.

Given the physical and chemical reactions of all materials for each unit of a given production process, the input-output relationship model for unit $(i, j)$ is developed as in Sun and Cai (2009):

$F_{i-1}^{j}+\alpha_{i}^{j}+\beta_{m, i}^{j}+\beta_{i, i}^{j}=F_{i}^{j}+\gamma_{i}^{j}+\beta_{i, k}^{j}+\beta_{i, i}^{j}$

Therefore, the parameters and evaluating index of material flow of unit $(i, j)$ are discussed in the following.

Waste rate $\left(w_{i}^{j}\right)$ is defined as the waste produced per unit of quantified products of unit $(i, j)$ and is expressed as follows:

$w_{i}^{j}=\left(\gamma_{i}^{j}+\beta_{i, k}^{j}+\beta_{i, i}^{j}\right) / F_{i}^{j}+\gamma_{i}^{j}+\beta_{i, k}^{j}+\beta_{i, i}^{j}$

Recycle rate of waste $\left(r_{i}^{j}\right)$ is defined as the rate of recycled waste to the total waste produced and is expressed as follows:

$r_{i}^{j}=\left(\beta_{i, k}^{j}+\beta_{i, i}^{j}\right) /\left(\gamma_{i}^{j}+\beta_{i, k}^{j}+\beta_{i, i}^{j}\right)$

Material efficiency $\left(e_{i}^{j}\right)$ is defined as the primary product in unit $(i, j)$ to total material input/output in this unit and is expressed as follows:

$$
\begin{aligned}
e_{i}^{j}= & F_{i}^{j} / F_{i}^{j}+\gamma_{i}^{j}+\beta_{i, k}^{j}+\beta_{i, i}^{j} \text { or } F_{i}^{j} / F_{i-1}^{j}+\alpha_{i}^{j}+\beta_{m, i}^{j} \\
& +\beta_{i, i}^{j} \text { or }\left(1-w_{i}^{j}\right)
\end{aligned}
$$

Similarly, material balance of stage $(i)$ is expressed as follows:

$F_{i-1}+\alpha_{i}+\beta_{m, i}+\beta_{i, i}=F_{i}+\gamma_{i}+\beta_{i, k}+\beta_{i, i}$

Likewise, the parameters of material flow in stage $i$ are waste rate $\left(w_{i}\right)$, waste recycle rate $\left(r_{i}\right)$, and material efficiency $\left(e_{i}\right)$. They are expressed as

$w_{i}=\frac{\gamma_{i}+\beta_{i, k}+\beta_{i, i}}{F_{i}+\gamma_{i}+\beta_{i, k}+\beta_{i, i}}$

$r_{i}=\frac{\beta_{i, k}+\beta_{i, i}}{\gamma_{i}+\beta_{i, k}+\beta_{i, i}}$

$e_{i}=\frac{F_{i}}{F_{i}+\gamma_{i}+\beta_{i, k}+\beta_{i, i}}=\frac{F_{i}}{F_{i-1}+\alpha_{i}+\beta_{m, i}+\beta_{i, i}}=\left(1-w_{i}\right)$

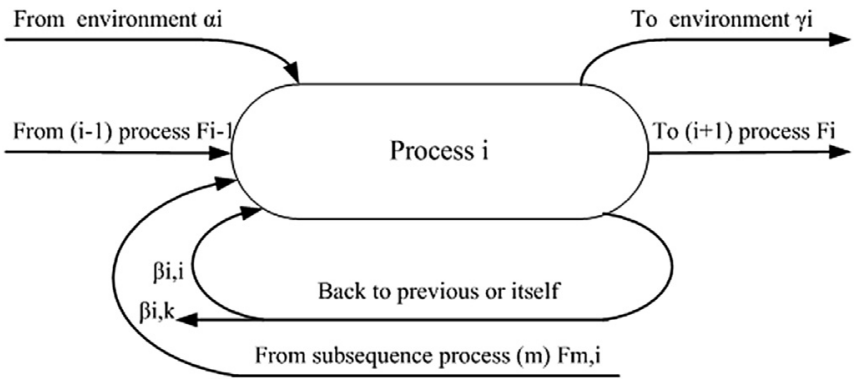

Fig. 6. Material flow model of a unit.

\subsection{Research boundary and calculated items}

In this paper, the general system boundary is first defined. For the current study, eight primary units are defined: crushing materials into a crusher, grinding the raw materials in a raw mill, preheating and calcining the raw meal in a pre-processing tower, burning the calcined raw meal in a rotary kiln, grinding coal, cooling the hot clinker in a cooler, grinding the clinker and additive in a cement mill, and blending and storing the cement (Fig. 5). Five units $(2,3,4,6$, and 7$)$ are mainly studied in section 4 .

Various raw materials are extracted for the manufacture of cement. Although more than 30 raw materials are used to provide the calcareous, aluminous, ferrous, and siliceous elements (Worrell et al., 2001), the most common raw materials used for the manufacture of cement are limestone, chalk, and clay. Electricity and diesel fuel are used to power heavy equipment for the mining and crushing process. The mass balance analysis of this study primarily focuses on the input of the raw materials (limestone, chalk, sandstone, clay, iron ore, and gypsum), ambient air, and fuels. Water, which is continually recycled, and electricity, which produces the shaft work in the system, are not considered in this study.

\section{Empirical study of a type of cement plant}

The LN cement plant, located in the south-west of Shandong Province, was considered as a case study for the mass flow and balance analysis. This cement plant operates on a dry process line with a five-stage suspension pre-heater and an inline pre-calciner. The kiln is $4 \mathrm{~m}$ in diameter and $60 \mathrm{~m}$ in length. The average daily production capacity is $2500 \mathrm{t}$ of clinker. The primary device configuration of this production line is listed in Table 1 . The given and calculated values include the raw material flow rate, input, output, and density of ambient air and waste gas volumes. The locations of testing points in the production line are listed in Fig. 5. The system data were documented accordingly over a long period of time. The average values of each set of data are employed throughout the study. All relevant data used for the analysis were obtained either from the plant control panel or by on-site measurement using the relevant instruments under normal operating conditions. The quantity of leaked air was estimated from the difference between the mass input and output. The following input data were used for the mass balance calculation: composition of raw meal, ultimate analysis of the fuel, dust content in the exhaust gas, loss of ignition, and exhaust gas composition in the suspension pre-heater. The mass balance was examined for the LN cement production system.

\subsection{Mass balance in raw mill system}

Operation of the system involves input of materials, hot gas, and ambient air. The output includes raw meal, steam, and exhaust gas and dust. A mixed material, having a humidity rate of $2.82 \%$, moves from the material silos into the raw mill. The kiln exit gases are conditioned in the gas conditioning tower to leave at $528.15 \mathrm{~K}$, for pre-heating and drying the feed to the raw mill. In the mill, the mixed and dried materials exit as raw meal with a humidity rate of $0.48 \%$, after grinding.

According to the investigation, a balance has been set between the input and output material in the raw mill system (Table 2). Table 2 indicates that the total input materials used in the raw meal production were $2.48 \mathrm{~kg} / \mathrm{kg}$ of raw meal, and that hot gas from the kiln and natural resources (limestone, silica, iron ore, and clay) are the primary sources accounting for $40.79 \%(1.01 \mathrm{~kg} / \mathrm{kg}$ raw meal) and $39.50 \%$ ( $0.98 \mathrm{~kg} / \mathrm{kg}$ raw meal) of farine production. Comparing this mass balance with those of other studies, it was found that the 
Table 1

Primary device configuration of LN cement production line.

\begin{tabular}{|c|c|c|c|c|}
\hline Process & Units & Equipment & Specification/type & Production capacity \\
\hline \multirow[t]{6}{*}{ Raw material preparation } & 1 & Crusher & PCF2022 & $500 \mathrm{t} / \mathrm{h}$ \\
\hline & 2 & V-separator & VX9620F & $234,500 \mathrm{~m}^{3} / \mathrm{h}$ \\
\hline & & Dynamic separator & RD4080 & $340,000 \mathrm{~m}^{3} / \mathrm{h}, 220 \mathrm{t} / \mathrm{h}$ \\
\hline & & Roller press & VR170-120 & $640 \mathrm{t} / \mathrm{h}$ \\
\hline & & Dust collection bags & Jlmb-340-2*6 & $244,800-489,600 \mathrm{~m}^{3} / \mathrm{h}$ \\
\hline & & Main fan & 3200DIBBR4 & $400,000 \mathrm{~m}^{3} / \mathrm{h}$ \\
\hline \multirow[t]{14}{*}{ Clinker production } & 3 & Conditioning tower & $\Phi 8.5 \times 34 \mathrm{~m}$ & \\
\hline & & ESP fan (kiln tail) & WDJ171-3 & $480,000 \mathrm{~m}^{3} / \mathrm{h}$ \\
\hline & & Pre-heater & $\begin{array}{l}\text { C1:2- } \Phi 5000 \mathrm{~mm}, \mathrm{C} 2: \Phi 6700 \mathrm{~mm}, \mathrm{C} 3 \text { and } \\
\text { C4: } \Phi 6950 \mathrm{~mm}, \mathrm{C} 5: \Phi 7250 \mathrm{~mm}\end{array}$ & $2500 \mathrm{t} / \mathrm{d}$ \\
\hline & & Pre-calciner & RSR $\Phi 5750 \times 28000$ & $2500 \mathrm{t} / \mathrm{d}$ \\
\hline & & High temperature fan (kiln) & 3050DIBB24 & $480,000 \mathrm{~m}^{3} / \mathrm{h}$ \\
\hline & & Coal combustion nozzle (pre-calciner) & BK10027 & $4500 \mathrm{~m}^{3} / \mathrm{h}$ \\
\hline & 4 & Rotary kiln & $\Phi 4 \times 60 \mathrm{~m}$ & $2500 \mathrm{t} / \mathrm{d}$ \\
\hline & & Coal combustion nozzle (kiln) & BK10016 & $2100 \mathrm{~m}^{3} / \mathrm{h}$ \\
\hline & & Primary air fan & BK9030 & $5304 \mathrm{~m}^{3} / \mathrm{h}$ \\
\hline & 5 & Grate cooler & CTBL & $258,650 \mathrm{~m}^{3} / \mathrm{h}$ \\
\hline & & Dust collection bags (grate cooler) & Y4-73N1.25.5D & $400,000 \mathrm{~m}^{3} / \mathrm{h}$ \\
\hline & 6 & Coal mill & $\Phi 3.2 \mathrm{~m} \times(6.5+2.5) \mathrm{m}$ & $20 \mathrm{t} / \mathrm{h}$ \\
\hline & & Separator (coal mill) & MD850A & \\
\hline & & Filter bag (coal mill) & $6-29 N 016 \mathrm{D}$ & $50,000 \mathrm{~m}^{3} / \mathrm{h}$ \\
\hline \multirow[t]{8}{*}{ Cement grinding } & 7 & V-separator & HFV350 & $180,000-240,000 \mathrm{~m}^{3} / \mathrm{h}$ \\
\hline & & Roller press & $\Phi 1600 \mathrm{~mm} \times 1400 \mathrm{~mm}$ & $675-780 \mathrm{t} / \mathrm{h}$ \\
\hline & & Cyclone dust collector & $2-\Phi 4100 \mathrm{~mm}$ & $240,000-260,000 \mathrm{~m}^{3} / \mathrm{h}$ \\
\hline & & Vortex classifier & N4250 & $255,000 \mathrm{~m}^{3} / \mathrm{h}$ \\
\hline & & Filter bag for vortex classifier & - & $263,000 \mathrm{~m}^{3} / \mathrm{h}$ \\
\hline & & Filter bag for cement mill & - & $60,000 \mathrm{~m}^{3} / \mathrm{h}$ \\
\hline & & Cement mill & $\Phi 4.8 \mathrm{~m} \times 9.5 \mathrm{~m}$ & $160-175 \mathrm{t} / \mathrm{h}$ \\
\hline & 8 & Cement silo & $\Phi 18 \mathrm{~m} \times 51 \mathrm{~m}$ & \\
\hline
\end{tabular}

amount of material required to produce a ton of raw meal given by Sogut et al. (2009) (2.64 kg/kg raw meal) is very similar to that used in this study, but raw meal accounting for output shows a much lower value (32.67\%). These differences can be attributed to the excess hot gas from the rotary being released into the raw mill system. However, waste gas discharged from dust collection bags and raw meal are the two main output sources, discharging $1.45 \mathrm{~kg} /$ $\mathrm{kg}$ raw meal and $1.00 \mathrm{~kg} / \mathrm{kg}$ raw meal, which is approximately $58.41 \%$ and $40.37 \%$ of the total output. Additionally, there is a $0.002 \mathrm{~kg} / \mathrm{kg}$ raw meal $(0.09 \%)$ difference in mass from the input materials for different reasons.
From the mass balance analysis results, mass flow diagrams for the input and output materials and flows in the roller press mill system were prepared. The materials from the roller press $(646.48 \mathrm{t} / \mathrm{h})$ and the new input materials $(225.42 \mathrm{t} / \mathrm{h})$ were divided into two groups in the $\mathrm{V}$-separator. The coarse materials from the classifier, accounting for $46.02 \%$ of the input raw materials, returned to the roller press, and the fine materials (53.92\%), together with the gas and leaking air, were transported to the dynamic separator for further filtering. Approximately $225 \mathrm{t} / \mathrm{h}$ of raw meal and $299,715 \mathrm{~m}^{3}$ of waste gas from the dynamic separator were placed into dust collection bags, and

Table 2

Mass balance of the raw mill under investigation.

\begin{tabular}{|c|c|c|c|}
\hline Description & Equations use & Data & Result (kg/kg-raw meal) \\
\hline \multicolumn{4}{|l|}{ Input materials } \\
\hline Limestone input & $\mathrm{m}_{\mathrm{li}}=\mathrm{M}_{\mathrm{li}} / \mathrm{M}_{\mathrm{s}}$ & $\mathrm{M}_{\mathrm{li}}=196.40 \mathrm{t} / \mathrm{h}, \mathrm{M}_{\mathrm{s}}=223.92 \mathrm{t} / \mathrm{h}$ & $0.88(35.41 \%)$ \\
\hline Silica input & $\mathrm{m}_{\mathrm{si}}=\mathrm{M}_{\mathrm{si}} / \mathrm{M}_{\mathrm{s}}$ & $\mathrm{M}_{\mathrm{si}}=13.63 \mathrm{t} / \mathrm{h}$ & $0.06(2.46 \%)$ \\
\hline Iron ore input & $\mathrm{m}_{\mathrm{io}}=\mathrm{M}_{\mathrm{io}} / \mathrm{M}_{\mathrm{s}}$ & $\mathrm{M}_{\mathrm{io}}=4.29 \mathrm{t} / \mathrm{h}$ & $0.02(0.77 \%)$ \\
\hline Clay input & $\mathrm{m}_{\mathrm{c}}=\mathrm{M}_{\mathrm{c}} / \mathrm{M}_{\mathrm{s}}$ & $\mathrm{M}_{\mathrm{c}}=4.79 \mathrm{t} / \mathrm{h}$ & $0.02(0.86 \%)$ \\
\hline Moisture in the limestone & $\mathrm{m}_{\mathrm{wli}}=\mathrm{M}_{\mathrm{li}}{ }^{*} \mathrm{C}_{\mathrm{wli}}$ & $C_{\text {wli }}=0.80 \%$ & $0.01(0.29 \%)$ \\
\hline Moisture in the silica & $\mathrm{m}_{\mathrm{wsi}}=\mathrm{M}_{\mathrm{si}}^{*} \mathrm{C}_{\mathrm{wsi}}$ & $C_{w s i}=10.96 \%$ & $0.01(0.30 \%)$ \\
\hline Moisture in the iron ore & $\mathrm{m}_{\text {wio }}=\mathrm{M}_{\mathrm{io}}{ }^{*} \mathrm{C}_{\text {wio }}$ & $C_{\text {wio }}=32.81 \%$ & $0.01(0.38 \%)$ \\
\hline Moisture in the clay & $\mathrm{m}_{\mathrm{wc}}=\mathrm{M}_{\mathrm{c}}{ }^{*} \mathrm{C}_{\mathrm{wc}}$ & $C_{w c}=16.67 \%$ & $0.00(0.17 \%)$ \\
\hline Dust in the gas & $\mathrm{m}_{\mathrm{dgr}}=\mathrm{V}_{\mathrm{g}}{ }^{*} \mathrm{~K}_{\mathrm{dgr}} / \mathrm{M}_{\mathrm{s}}$ & $\mathrm{V}_{\mathrm{g}}=175,000 \mathrm{~m}^{3} / \mathrm{h}, \mathrm{K}_{\mathrm{dgr}}=30 \mathrm{~g} / \mathrm{m}^{3}$ & $0.02(0.96 \%)$ \\
\hline Air & $\mathrm{m}_{\mathrm{g}}=\mathrm{V}_{\mathrm{g}}^{*} \rho_{\mathrm{a}}$ & $\rho_{\mathrm{a}}=1.29 \mathrm{~kg} / \mathrm{m}^{3}$ & $1.01(40.79 \%)$ \\
\hline Leaking air & $\mathrm{m}_{\mathrm{lar}}=\mathrm{V}_{\mathrm{lar}}{ }^{*} \rho_{\mathrm{a}} / \mathrm{M}_{\mathrm{s}}$ & $\mathrm{V}_{\mathrm{lar}}=10,500 \mathrm{~m}^{3} / \mathrm{h}$ & $0.06(2.45 \%)$ \\
\hline Air put into dynamic separator and dust collection bags & $\mathrm{m}_{\mathrm{ads}}=\left(\mathrm{V}_{\mathrm{ads}}{ }^{*}+\mathrm{V}_{\mathrm{adcb}}\right)^{*} \rho_{\mathrm{a}} / \mathrm{M}_{\mathrm{s}}$ & $\mathrm{V}_{\mathrm{ads}}=1,700 \mathrm{~m}^{3} / \mathrm{h}, \mathrm{V}_{\mathrm{adcb}}=3515 \mathrm{~m}^{3} / \mathrm{h}$ & $0.03(1.22 \%)$ \\
\hline Air put into roller crusher & $\mathrm{m}_{\mathrm{arc}}=\mathrm{V}_{\mathrm{arc}}{ }^{*} \rho_{\mathrm{a}} / \mathrm{M}_{\mathrm{s}}$ & $\mathrm{V}_{\mathrm{arc}}=60,000 \mathrm{~m}^{3} / \mathrm{h}$ & $0.35(13.95 \%)$ \\
\hline Total input & & & $2.48(100 \%)$ \\
\hline \multicolumn{4}{|l|}{ Output materials } \\
\hline Raw meal & $\mathrm{m}_{\mathrm{s}}=\mathrm{M}_{\mathrm{s}} / \mathrm{M}_{\mathrm{s}}$ & & $1.00(40.37 \%)$ \\
\hline Moisture in raw meal & $\mathrm{m}_{\mathrm{ws}}=\mathrm{M}_{\mathrm{s}}{ }^{*} \mathrm{C}_{\mathrm{ws}} / \mathrm{M}_{\mathrm{s}}$ & $\mathrm{C}_{\mathrm{ws}}=0.48 \%$ & $0.01(0.20 \%)$ \\
\hline Waste gas $\left(\mathrm{CO}_{2}, \mathrm{~N}_{2}, \mathrm{NO}_{\mathrm{X}}, \mathrm{SO}_{2} \mathrm{CO}, \mathrm{H}_{2} \mathrm{O}\right.$, etc $)$ & $\mathrm{m}_{\mathrm{ga}}=\mathrm{V}_{\mathrm{ga}}{ }^{*} \rho_{\mathrm{a}} / \mathrm{M}_{\mathrm{s}}$ & $\mathrm{V}_{\mathrm{ga}}=250,715 \mathrm{~m}^{3} / \mathrm{h}$ & $1.45(58.41 \%)$ \\
\hline Dust in waste gas & $\mathrm{m}_{\mathrm{gad}}=\mathrm{V}_{\mathrm{ga}}{ }^{*} \mathrm{~K}_{\mathrm{gad}} / \mathrm{M}_{\mathrm{s}}$ & $\mathrm{K}_{\mathrm{gad}}=30 \mathrm{mg} / \mathrm{m}^{3}$ & $0.00(0.00 \%)$ \\
\hline Steam & $\mathrm{m}_{\mathrm{st}}=\mathrm{m}_{\mathrm{wli}}+\mathrm{m}_{\mathrm{wsi}}+\mathrm{m}_{\mathrm{wio}}+\mathrm{m}_{\mathrm{wc}}-\mathrm{m}_{\mathrm{ws}}$ & & $0.02(0.94 \%)$ \\
\hline Unaccounted losses & $\mathrm{m}_{\mathrm{los}}=1-\mathrm{m}_{\mathrm{s}}-\mathrm{m}_{\mathrm{ws}}-\mathrm{m}_{\mathrm{ga}}-\mathrm{m}_{\mathrm{gad}}-\mathrm{m}_{\mathrm{st}}$ & & $0.002(0.09 \%)$ \\
\hline Total output & & & $2.48(100 \%)$ \\
\hline
\end{tabular}


materials that were not of a suitable size, together with coarse material from the V-separator, were milled in the roller press and conveyed to the $\mathrm{V}$-separator for classification. Fig. 7 shows a Sankey diagram, which indicates the magnitude of material flows in the raw mill system.

\subsection{Mass balance in clinker production system}

The mass balance was examined for clinker production and across the boundary of the kiln system, which included the pyroprocessing (unit 3), kiln (unit 4), and cooler (unit 6) units, but did not include the coal mill (unit 5) (Fig. 8). The streams entering the system are raw meal, air into the kiln and cooler, and coal fired into the kiln and calciner. The streams leaving the system are clinker from the cooler, exhaust gases from the pre-heater, and hot air from the cooler. Relatively good consistency is obtained between the total material input and total output in clinker production (Fig. 8, Table 3). The pertinent equations used for evaluating the different components of the system mass balance and the relevant obtained data and constants are listed in Table 3. The complete material balance for the kiln system is shown in Table 3. As seen in Table 3, the total material used in the clinker process is $4.69 \mathrm{~kg} / \mathrm{kg}$ clinker, and the primary material sources are the cooling air-producing total material of $2.33 \mathrm{~kg} / \mathrm{kg}$ clinker (49.60\%) - and raw meal ( $1.56 \mathrm{~kg} / \mathrm{kg}$ clinker), accounting for $33.29 \%$ of the required material. The raw meal to clinker ratio (1.56) determined in this work is the lowest compared with that determined by Low (2005) (1.65), Atmaca and Yumrutaş (2014) (1.59), and Kapur et al. (2009) (1.61); however, the raw meal to clinker ratio determined in this work was higher than that determined by Gao et al. (2014) (1.51). The primary reason, as pointed out by Gao et al. (2014), is the differences in clinker quality and energy intensity. The amount of waste gas discharged from the cooler according to this present study and that according to Atmaca and Yumrutaş (2014) are very similar; the amount of waste gas discharged from the pre-heater is remarkably different owing to leaking and lower utilization of this waste gas. In this study, most of the material loss and dust emission sources have been considered. There is only a $0.07 \mathrm{~kg} / \mathrm{kg}$ clinker (1.53\%) difference in mass from the input materials, and the amount of sensible materials discharged in air with the exhaust gas from different parts of the kiln is small. The total sensible material discharged with gas is approximately $0.11 \mathrm{~kg} / \mathrm{kg}$ clinker, accounting for $2.34 \%$ of the total material output. Waste gas from the pre-heater $(1.92 \mathrm{~kg} / \mathrm{kg}$ clinker), high-temperature gas from the cooler (1.06 kg/kg clinker),

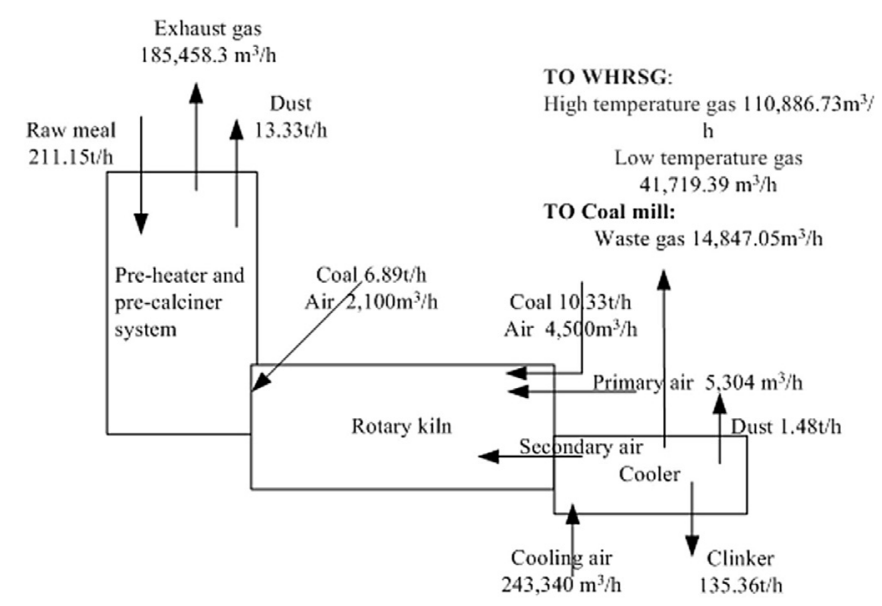

Fig. 8. Input-output materials in kiln system.

and clinker $(0.99 \mathrm{~kg} / \mathrm{kg}$ clinker) are the three primary output sources of material; they account for approximately $40.90 \%, 22.60 \%$, and $21.11 \%$ of the total output, respectively.

To better represent the sequence of flows, the results are presented diagrammatically (Fig. 9). In the kiln system, the material and gas flow in opposite direction. During this process, $211.15 \mathrm{t} / \mathrm{h}$ of raw meal and $6.88 \mathrm{t} / \mathrm{h}$ of coal are fed to the pyro-processing unit, and only $150.90 \mathrm{t} / \mathrm{h}$ of calcined raw meal is transported to the kiln. Approximately $85 \%$ of the carbonate breaks down during this process in the surveyed plant. This implies that $28.53 \%$ of the raw meal's weight is lost in units 3 and 4. During the clinkerization process (unit 6), the calcined materials are heated to $1723.15 \mathrm{~K}$ and undergo a series of physical and chemical changes that turn raw meal into clinker. During his time, $135.35 \mathrm{t} / \mathrm{h}$ of clinker is produced and rapidly air-cooled to prevent further chemical changes; $314.62 \mathrm{t} / \mathrm{h}\left(243,340 \mathrm{~m}^{3} / \mathrm{h}\right)$ of ambient air is entered into the cooler for cooling clinker; $216.51 \mathrm{t} / \mathrm{h}$ of hot air from the clinker cooler is recovered and used for other purposes. The remaining air (98.11 t/ h) returns to the kiln and is used as burning air. In units 3 and 4 , $82.85 \mathrm{t} / \mathrm{h}$ of air is leaked from the kiln and $8.54 \mathrm{t} / \mathrm{h}$ is fed with coal in the calciner and head of the kiln. This input air, along with the emissions leaving the material $(259.46 \mathrm{t} / \mathrm{h})$, is discharged from the top of the pre-heater. Part of the raw meal $(13.30 \mathrm{t} / \mathrm{h})$ is carried by waste gas and leaves the system.

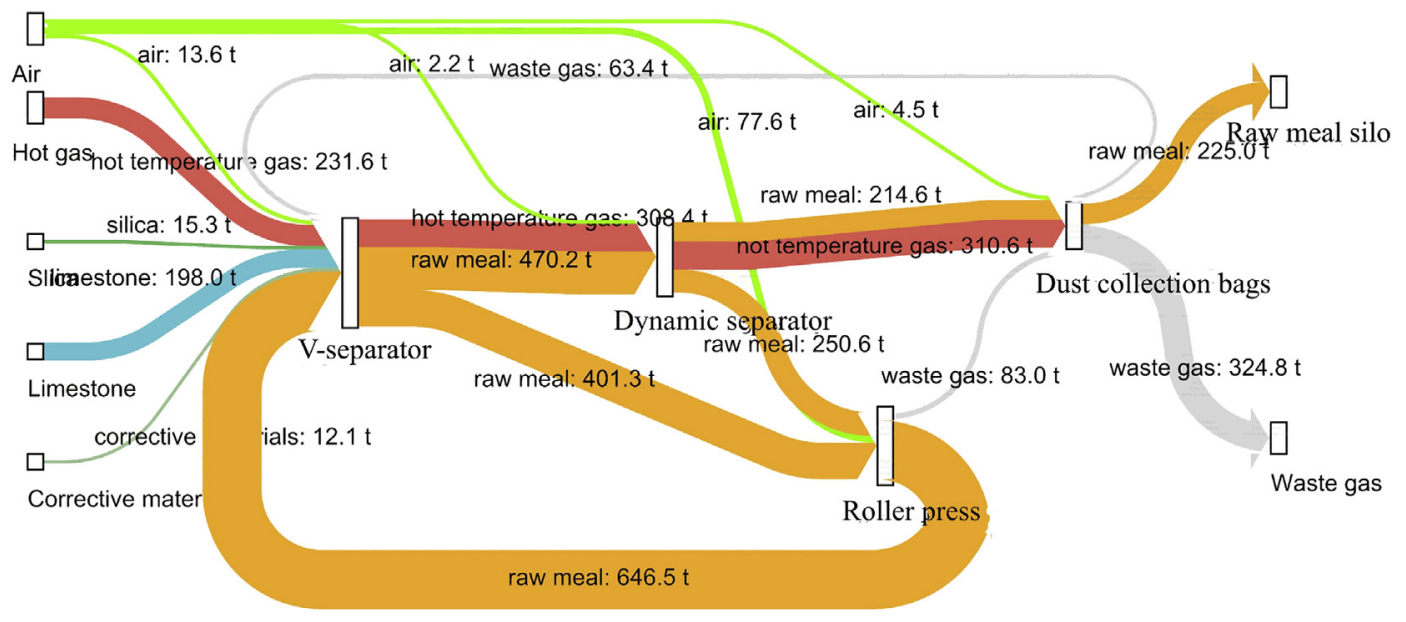

Fig. 7. Sankey diagram of raw roller mill system. 
Table 3

Complete material balance of kiln system.

\begin{tabular}{|c|c|c|c|}
\hline Description & Equations use & Data & $\begin{array}{l}\text { Result } \\
(\mathrm{kg} / \mathrm{kg} \text {-clinker })\end{array}$ \\
\hline \multicolumn{4}{|l|}{ Material inputs } \\
\hline Fuel consumption & $\mathrm{m}_{\mathrm{r}}=\mathrm{M}_{\mathrm{r}} / \mathrm{M}_{\mathrm{sh}}$ & $\begin{array}{l}\mathrm{M}_{\mathrm{r}}=17,200 \mathrm{~kg} / \mathrm{h} \\
\mathrm{M}_{\mathrm{sh}}=135,355 \mathrm{~kg} \text {-clinker } / \mathrm{h}\end{array}$ & $0.13(2.71 \%)$ \\
\hline Raw meal consumption & $\mathrm{m}_{\mathrm{s}}=\mathrm{M}_{\mathrm{s}} / \mathrm{M}_{\mathrm{sh}}$ & $\mathrm{M}_{\mathrm{s}}=211,154 \mathrm{~kg} / \mathrm{h}$ & $1.56(33.29 \%)$ \\
\hline Primary air into the kiln & $\mathrm{m}_{\mathrm{lk}}=\mathrm{V}_{\mathrm{lk}} / \mathrm{M}_{\mathrm{sh}}{ }^{*} \rho_{\mathrm{k}}$ & $\mathrm{V}_{\mathrm{lk}}=5,304 \mathrm{~m}^{3} / \mathrm{h}, \rho_{\mathrm{k}}=1.293 \mathrm{~kg} / \mathrm{m}^{3}$ & $0.05(1.08 \%)$ \\
\hline Air into the kiln with coal & $\mathrm{m}_{\mathrm{yk}}=\mathrm{V}_{\mathrm{yk}} / \mathrm{M}_{\mathrm{sh}}{ }^{*} \rho_{\mathrm{k}}$ & $\mathrm{V}_{\mathrm{yk}}=2100 \mathrm{~m}^{3} / \mathrm{h}$ & $0.02(0.43 \%)$ \\
\hline Air into the calciner with coal & $\mathrm{m}_{\mathrm{lf}}=\mathrm{V}_{\mathrm{lf}} / \mathrm{M}_{\mathrm{sh}}{ }^{*} \rho_{\mathrm{k}}$ & $\mathrm{V}_{\mathrm{lf}}=4500 \mathrm{~m}^{3} / \mathrm{h}$ & $0.04(0.92 \%)$ \\
\hline Air into the cooler & $\mathrm{m}_{\mathrm{lk}}=\mathrm{V}_{\mathrm{Lk}} / \mathrm{M}_{\mathrm{sh}}^{*} \rho_{\mathrm{k}}$ & $\mathrm{V}_{\mathrm{Lk}}=243,340 \mathrm{~m}^{3} / \mathrm{h}$ & $2.33(49.60 \%)$ \\
\hline Air leaking into the kiln system & $\begin{array}{l}\mathrm{m}_{\mathrm{lok}}=1.01^{*}\left(\mathrm{Q}_{\mathrm{net}} \text { ar } / 4.1816+0.5\right)^{*} \mathrm{~m}_{\mathrm{r}}{ }^{*} \alpha_{\mathrm{f}} \\
*\left(\mathrm{~V}_{\mathrm{lk}}+\mathrm{V}_{\mathrm{yk}}+\mathrm{V}_{\mathrm{lf}}+\mathrm{V}_{\mathrm{Lk}}-\mathrm{V}_{\mathrm{Pk}}\right) / \mathrm{M}_{\mathrm{sh}}{ }^{*} \rho_{\mathrm{k}}\end{array}$ & $\begin{array}{l}\text { Qnet, ar }=25.620 \mathrm{MJ} / \mathrm{kg}, \alpha_{\mathrm{f}}=1.27 \\
\mathrm{~V}_{\mathrm{Pk}}=167,453.16 \mathrm{~m}^{3} / \mathrm{h}\end{array}$ & $0.56(11.98 \%)$ \\
\hline Total material input & & & $4.69(100 \%)$ \\
\hline \multicolumn{4}{|l|}{ Material outputs } \\
\hline Waste gas from pre-heater & $\begin{array}{l}\mathrm{m}_{\mathrm{f}}=\mathrm{V}_{\mathrm{f}} / \mathrm{M}_{\mathrm{sh}}{ }^{*}\left(\mathrm{CO}_{2} \% * 1.977+\mathrm{O}_{2} \% * 1.429\right. \\
\left.+\mathrm{CO} \%{ }^{*} 1.25+\mathrm{N}_{2} \% * 1.2505+\mathrm{H}_{2} \mathrm{O} \%{ }^{*} 0.804\right) / 100\end{array}$ & $V_{\mathrm{f}}=185,458.3 \mathrm{~m}^{3} / \mathrm{h}$ & $1.92(40.90 \%)$ \\
\hline CKD from pre-heater waste gas & $\mathrm{m}_{\mathrm{fh}}=\mathrm{K}_{\mathrm{fh}}{ }^{*} \mathrm{~V}_{\mathrm{f}} / \mathrm{M}_{\mathrm{sh}}$ & $\mathrm{K}_{\mathrm{fh}}=0.0724 \mathrm{~kg} / \mathrm{m}^{3}$ & $0.10(2.11 \%)$ \\
\hline High temperature gas to WHRSG from cooler & $\mathrm{m}_{\mathrm{gfdf}}=\mathrm{V}_{\mathrm{gfdf}} / \mathrm{M}_{\mathrm{sh}}{ }^{*} \rho_{\mathrm{k}}$ & $\mathrm{V}_{\mathrm{gfdf}}=110,886.73 \mathrm{~m}^{3} / \mathrm{h}$ & $1.06(22.60 \%)$ \\
\hline Low temperature gas to WHRSG from cooler & $\mathrm{m}_{\mathrm{dfdf}}=\mathrm{V}_{\mathrm{dfdf}} / \mathrm{M}_{\mathrm{sh}}{ }^{*} \rho_{\mathrm{k}}$ & $\mathrm{V}_{\mathrm{dfdf}}=41,719.39 \mathrm{~m}^{3} / \mathrm{h}$ & $0.40(8.50 \%)$ \\
\hline Waste gas from cooler to coal mill & $\mathrm{m}_{\mathrm{mmf}}=\mathrm{V}_{\mathrm{mmf}} / \mathrm{M}_{\mathrm{sh}}{ }^{*} \rho_{\mathrm{k}}$ & $\mathrm{V}_{\mathrm{mmf}}=14,847.05 \mathrm{~m}^{3} / \mathrm{h}$ & $0.14(3.03 \%)$ \\
\hline CKD from cooler high temperature gas & $\mathrm{m}_{\mathrm{gfdfh}}=\mathrm{K}_{\mathrm{gfdfh}} * \mathrm{~V}_{\mathrm{gfdf}} / \mathrm{M}_{\mathrm{sh}}$ & $\mathrm{K}_{\mathrm{gfdfh}}=8.97 \mathrm{~g} / \mathrm{m}^{3}$ & $0.01(0.16 \%)$ \\
\hline CKD from cooler low temperature gas & $\mathrm{m}_{\mathrm{dfdfh}}=\mathrm{K}_{\mathrm{dfdfh}} * \mathrm{~V}_{\mathrm{dfdf}} / \mathrm{M}_{\mathrm{sh}}$ & $\mathrm{K}_{\mathrm{dfdfh}}=9.09 \mathrm{~g} / \mathrm{m}^{3}$ & $0.00(0.06 \%)$ \\
\hline CKD from waste gas to coal mill & $\mathrm{m}_{\mathrm{mmfh}}=\mathrm{K}_{\mathrm{mmfh}}{ }^{*} \mathrm{~V}_{\mathrm{mmf}} / \mathrm{M}_{\mathrm{sh}}$ & $\mathrm{K}_{\mathrm{mmfh}}=6.01 \mathrm{~g} / \mathrm{m}^{3}$ & $0.00(0.02 \%)$ \\
\hline Clinker & $\mathrm{m}_{\mathrm{sh}}=1-\mathrm{m}_{1 \mathrm{gffdh}}-\mathrm{m}_{\mathrm{dfdfh}}-\mathrm{m}_{\mathrm{mmfh}}$ & & $0.99(21.11 \%)$ \\
\hline Unaccounted losses & & & $0.07(1.53 \%)$ \\
\hline Total material output & & & $4.687(100 \%)$ \\
\hline
\end{tabular}

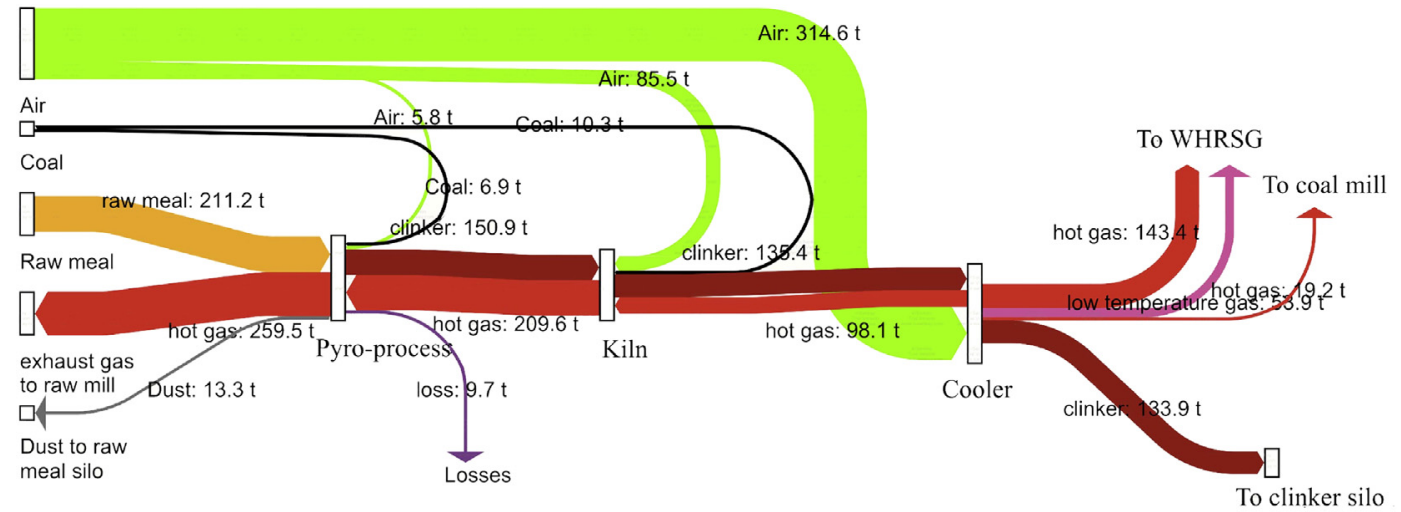

Fig. 9. Sankey diagram of clinker production system.

\subsection{Mass balance in cement grinding system}

During cement grinding, the clinker is ground with other materials (gypsum, limestone, natural pozzolan, or industrial byproducts) into a fine powder. The mix proportion of P.O. 42.5 cement in the investigated plants is listed in Table 4. Approximately $84.00 \%$ clinker, $4.00 \%$ gypsum, and $7.00 \%$ limestone are sent into a roller crusher to achieve a preliminary size reduction in the final stage. Next, these materials from the roller crusher with fly ash are sent through tube mills for further grinding.

According to the investigation, there is a balance between input and output material in the cement grinding system; the relevant data and equations to evaluate the different component of this system mass balance are listed in Table 6 . In the cement plant, $3.41 \mathrm{~kg}$ of materials is required to produce a $\mathrm{kg}$ of cement in the final stage. Ambient air (2.40 kg/kg cement) and clinker $(0.84 \mathrm{~kg} / \mathrm{kg}$ cement) are the main input sources, accounting for $70.33 \%$ and $24.66 \%$ of the total input (Table 5), respectively. The moisture contained in the input materials (clinker, gypsum, limestone, and fly ash) is approximately $1.81 \mathrm{t} / \mathrm{h}$, or approximately $0.31 \%$ of the total input. The separator and mill dust collectors are the primary waste gas discharge points in the final grinding stage, with discharges of approximately $329.72 \mathrm{t} / \mathrm{h}$ and $77.58 \mathrm{t} / \mathrm{h}$, sharing $56.94 \%$ and $13.40 \%$ of the total output, respectively. The quantity of the produced cement is approximately $169.86 \mathrm{t} / \mathrm{h}$, accounting for $29.33 \%$ of the total output. A minimal amount of dust is discharged into the air with the exhaust gas $(\approx 0.001 \%)$. The difference between the amounts of the input and output materials is approximately $0.13 \mathrm{t} / \mathrm{h}(0.02 \%)$. The clinker to cement ratios given by Atmaca and Yumrutaş (2014), Kapur et al. (2009), and Low (2005) are higher than the clinker to cement ratio in this study. These higher values indicate that more resources are required to produce a ton of cement. The waste gas, at a temperature of $353.15 \mathrm{~K}$, was

Table 4

Proportioning program of cement (P.O.42.5) in the surveyed plant.

\begin{tabular}{lllcc}
\hline Cement & Clinker/\% & Limestone/\% & Gypsum/\% & Fly ash/\% \\
\hline P.O. 42.5 & 84.00 & 7.00 & 4.00 & 5.00 \\
Moisture & - & 0.80 & 30.00 & 15.00 \\
\hline
\end{tabular}


Table 5

Mass balance of the cement mill system.

\begin{tabular}{|c|c|c|c|}
\hline Description & Equations use & Data & Result (kg/kg-cement) \\
\hline \multicolumn{4}{|l|}{ Input materials } \\
\hline Clinker consumption & $\mathrm{m}_{\mathrm{cc}}=\mathrm{M}_{\mathrm{cc}} / \mathrm{M}_{\mathrm{c}}$ & $\mathrm{M}_{\mathrm{li}}=142.8 \mathrm{t} / \mathrm{h}, \mathrm{M}_{\mathrm{c}}=169.86 \mathrm{t} / \mathrm{h}$ & $0.84(24.66 \%)$ \\
\hline Gypsum consumption & $\mathrm{m}_{\mathrm{gc}}=\mathrm{M}_{\mathrm{gc}} / \mathrm{M}_{\mathrm{c}}$ & $\mathrm{M}_{\mathrm{gc}}=6.80 \mathrm{t} / \mathrm{h}$ & $0.04(1.17 \%)$ \\
\hline Limestone consumption & $\mathrm{m}_{\text {lic }}=\mathrm{M}_{\mathrm{lic}} / \mathrm{M}_{\mathrm{c}}$ & $\mathrm{M}_{\text {lic }}=11.90 \mathrm{t} / \mathrm{h}$ & $0.07(2.06 \%)$ \\
\hline Fly ash consumption & $\mathrm{m}_{\mathrm{fac}}=\mathrm{M}_{\mathrm{fac}} / \mathrm{M}_{\mathrm{c}}$ & $\mathrm{M}_{\mathrm{fac}}=8.50 \mathrm{t} / \mathrm{h}$ & $0.05(1.47 \%)$ \\
\hline Moisture in the limestone & $\mathrm{m}_{\mathrm{wlic}}=\mathrm{M}_{\mathrm{lic}}{ }^{*} \mathrm{C}_{\mathrm{wli}} / \mathrm{M}_{\mathrm{c}}$ & $\mathrm{C}_{\mathrm{wli}}=0.80 \%$ & $0.00(0.02 \%)$ \\
\hline Moisture in the gypsum & $\mathrm{m}_{\mathrm{wgc}}=\mathrm{M}_{\mathrm{gc}}{ }^{*} \mathrm{C}_{\mathrm{wgc}} / \mathrm{M}_{\mathrm{c}}$ & $\mathrm{C}_{\mathrm{wgc}}=3.00 \%$ & $0.00(0.04)$ \\
\hline Moisture in the fly ash & $\mathrm{m}_{\mathrm{wfac}}=\mathrm{M}_{\mathrm{fac}}{ }^{*} \mathrm{C}_{\mathrm{wfac}} / \mathrm{M}_{\mathrm{c}}$ & $C_{\mathrm{wfac}}=15.00 \%$ & $0.01(0.26 \%)$ \\
\hline Air into V-separator & $\mathrm{m}_{\mathrm{avc}}=\mathrm{V}_{\mathrm{avc}}^{*} \rho_{\mathrm{a}} / \mathrm{M}_{\mathrm{c}}$ & $\mathrm{V}_{\mathrm{aac}}=232,000 \mathrm{~m}^{3} / \mathrm{h}, \rho_{\mathrm{a}}=1.29 \mathrm{~kg} / \mathrm{m}^{3}$ & $1.77(51.80 \%)$ \\
\hline Air into vortex classifier & $\mathrm{m}_{\mathrm{avc}}=\mathrm{V}_{\mathrm{avc}}{ }^{*} \rho_{\mathrm{a}} / \mathrm{M}_{\mathrm{c}}$ & $\mathrm{V}_{\mathrm{avc}}=23,000 \mathrm{~m}^{3} / \mathrm{h}$ & $0.18(5.14 \%)$ \\
\hline Air into cement mill & $\mathrm{m}_{\mathrm{ac}}=\mathrm{V}_{\mathrm{ac}}{ }^{*} \rho_{\mathrm{a}} / \mathrm{M}_{\mathrm{c}}$ & $\mathrm{V}_{\mathrm{ac}}=60,000 \mathrm{~m}^{3} / \mathrm{h}$ & $0.46(13.40 \%)$ \\
\hline Total input & & & $3.41(100 \%)$ \\
\hline \multicolumn{4}{|l|}{ Output materials } \\
\hline Cement & $\mathrm{m}_{\mathrm{c}}=\mathrm{M}_{\mathrm{c}} / \mathrm{M}_{\mathrm{c}}$ & & $1.00(29.33 \%)$ \\
\hline Gas from separator dust collector & $\mathrm{m}_{\mathrm{gcc}}=\mathrm{V}_{\mathrm{gcc}}{ }^{*} \rho_{\mathrm{a}} / \mathrm{M}_{\mathrm{c}}$ & $\mathrm{V}_{\mathrm{gcc}}=255,000 \mathrm{~m}^{3} / \mathrm{h}$ & $1.94(56.94 \%)$ \\
\hline Dust in separator dust collector gas & $\mathrm{m}_{\mathrm{gcd}}=\mathrm{V}_{\mathrm{gcc}}{ }^{*} \mathrm{~K}_{\mathrm{gcd}} / \mathrm{M}_{\mathrm{c}}$ & $\mathrm{K}_{\mathrm{gcd}}=20 \mathrm{mg} / \mathrm{m}^{3}$ & $3 \mathrm{E}-05(0.00 \%)$ \\
\hline Gas from mill dust collector & $\mathrm{m}_{\mathrm{gcmc}}=\mathrm{V}_{\mathrm{gcmc}}{ }^{*} \rho_{\mathrm{a}} / \mathrm{M}_{\mathrm{c}}$ & $\mathrm{V}_{\mathrm{gcmc}}=60,000 \mathrm{~m}^{3} / \mathrm{h}$ & $0.46(13.40 \%)$ \\
\hline Dust in mill dust collector gas & $\mathrm{m}_{\mathrm{gmcd}}=\mathrm{V}_{\mathrm{gcmc}}{ }^{*} \mathrm{~K}_{\mathrm{gmcd}} / \mathrm{M}_{\mathrm{c}}$ & $\mathrm{K}_{\mathrm{gmcd}}=25 \mathrm{mg} / \mathrm{m}^{3}$ & $8.83 \mathrm{E}-06(0.00 \%)$ \\
\hline Steam & $\mathrm{m}_{\mathrm{sc}}=\mathrm{m}_{\mathrm{wli}}+\mathrm{m}_{\mathrm{wg}}+\mathrm{m}_{\mathrm{wfa}}$ & & $0.01(0.31 \%)$ \\
\hline Unaccounted losses & & & $0.00(0.02 \%)$ \\
\hline Total output & & & $3.41(100 \%)$ \\
\hline
\end{tabular}

Table 6

Material efficiency in different units and stages.

\begin{tabular}{|c|c|c|c|c|c|}
\hline Unit & Raw mill & Pyro-processing & Rotary kiln & Clinker cooler & Cement mill \\
\hline Waste rate & $63.31 \%$ & $65.18 \%$ & $60.76 \%$ & $70.24 \%$ & $74.12 \%$ \\
\hline Recycle rate of waste & $16.33 \%$ & $81.98 \%$ & $100.00 \%$ & $99.53 \%$ & $0.00 \%$ \\
\hline Stage & Raw meal preparation & Clinker production & & & Cement grinding \\
\hline Waste rate & $63.31 \%$ & $78.89 \%$ & & & $74.12 \%$ \\
\hline Recycle rate of waste & $16.33 \%$ & $70.71 \%$ & & & $0.00 \%$ \\
\hline
\end{tabular}

not recycled for other purposes in any of the past studies reported in the literature.

Fig. 10 shows the material flow diagram of the cement grinding system. Clinker $(142.80 \mathrm{t} / \mathrm{h})$, limestone $(7.01 \mathrm{t} / \mathrm{h})$ and gypsum $(12.00 \mathrm{t} / \mathrm{h})$ are classified in the $\mathrm{V}$-separator with the materials returned $(465.11 \mathrm{t} / \mathrm{h})$ from the roller press. Part of the material $(158.10 \mathrm{t} / \mathrm{h})$ is carried by the input air $(299.98 \mathrm{t} / \mathrm{h})$ and conveyed into the cyclone dust collector, and the remaining is transported into the roller press for crushing. The materials in the cyclone dust collector are divided into two parts. The primary part materials (133.93 $\mathrm{t} / \mathrm{h}$ ) flow into the cement mill for grinding, and then elevated to the vortex classifier. The materials from the cement mill and the cyclone dust collector are classified according to their size. The coarse material $(63.23 \mathrm{t} / \mathrm{h})$, accounting for $26.97 \%$ of the input raw materials of the classifier $(234.39 \mathrm{t} / \mathrm{h})$, return to the cement mill, and the fine materials (73.02\%), together with the waste gas and leaked air $(299.98 \mathrm{t} / \mathrm{h})$, are transported to dust collection bags. In this case, $169.86 \mathrm{t} / \mathrm{h}$ of cement and $486.67 \mathrm{t} / \mathrm{h}$ of waste gas are discharged, and they leave the system.

\subsection{Material efficiency of unit or stage}

By following the preceding analysis, the material flow profile of the investigated cement plant was established, as shown in Fig. 11. As shown in Fig. 11, $1.21 \mathrm{t}$ of limestone, $5.81 \mathrm{t}$ of air, and $0.40 \mathrm{t}$ of other materials (silica, corrective materials, gypsum, fly ash, and coal) are required for manufacturing one ton of cement. Meanwhile, $4.79 \mathrm{t}$ of waste gases are discharged into the atmosphere, $1.51 \mathrm{t}$ of high- and low-temperature gases are recycled to generate electricity, and $0.12 \mathrm{t}$ of hot air is reused for drying coal. Using Eqs. (1)-(6) (section 3.1) and the investigated data (sections 4.1-4.3), the material efficiency of the investigated plant during different units and stages are determined (Table 6 ). Waste gases, the primary output of these cement units $(2,3,4,6$, and 7$)$, account for more than half of their outputs. The waste rates in these units are $63.31 \%$, $65.18 \%, 60.76 \%, 70.24 \%$, and $74.12 \%$ (Table 6), whereas the recycle rates are significantly different. During clinker production, highand low-temperature gases discharged from the kiln, clinker cooler, and pre-heater are used for other purposes, such as firing the kiln, drying raw materials and coal, and driving the steam turbine to generate electricity. The recycle rate of waste is $70.71 \%$ in the surveyed plant (Table 6). The available waste energy is used to power a steam turbine driven by an electrical generator. This generated electricity offsets a portion of the purchased electricity. The wasteheat-utilization industry is developing technologies to increase the potential for energy recovery. Electricity recovery capacity was approximately $34 \mathrm{kWh}$ per ton of clinker produced for dry rotary kilns (Tang, 2010). If $34 \mathrm{kWh}$ energy recovery per ton of clinker produced was considered for this plant, then the potential environmental impact on global warming, respiratory inorganics, and non-renewable energy categories will be decreased by $2.88 \times 10^{-2} \mathrm{~kg} \mathrm{PM}{ }_{2.5}, 26.48 \mathrm{~kg} \mathrm{CO}$, and $310.77 \mathrm{MJ}$ primary energy (Chen et al., 2014).

However, the waste gases discharged from the raw and cement mills at a temperature of $353.15 \mathrm{~K}$ are released into the atmosphere (Sogut et al., 2009). Their recycle rates of waste during the raw meal preparation and cement grinding stages are $16.33 \%$ and $0.00 \%$, respectively. This difference is due to the fact that only part of the waste gas is reused in the cycle; most of it is not used for other purposes as clinker waste gas. However, this waste gas can be used to meet the demands for heat supply, showers, and washing in homes or plants. According to the Emissions Standard 


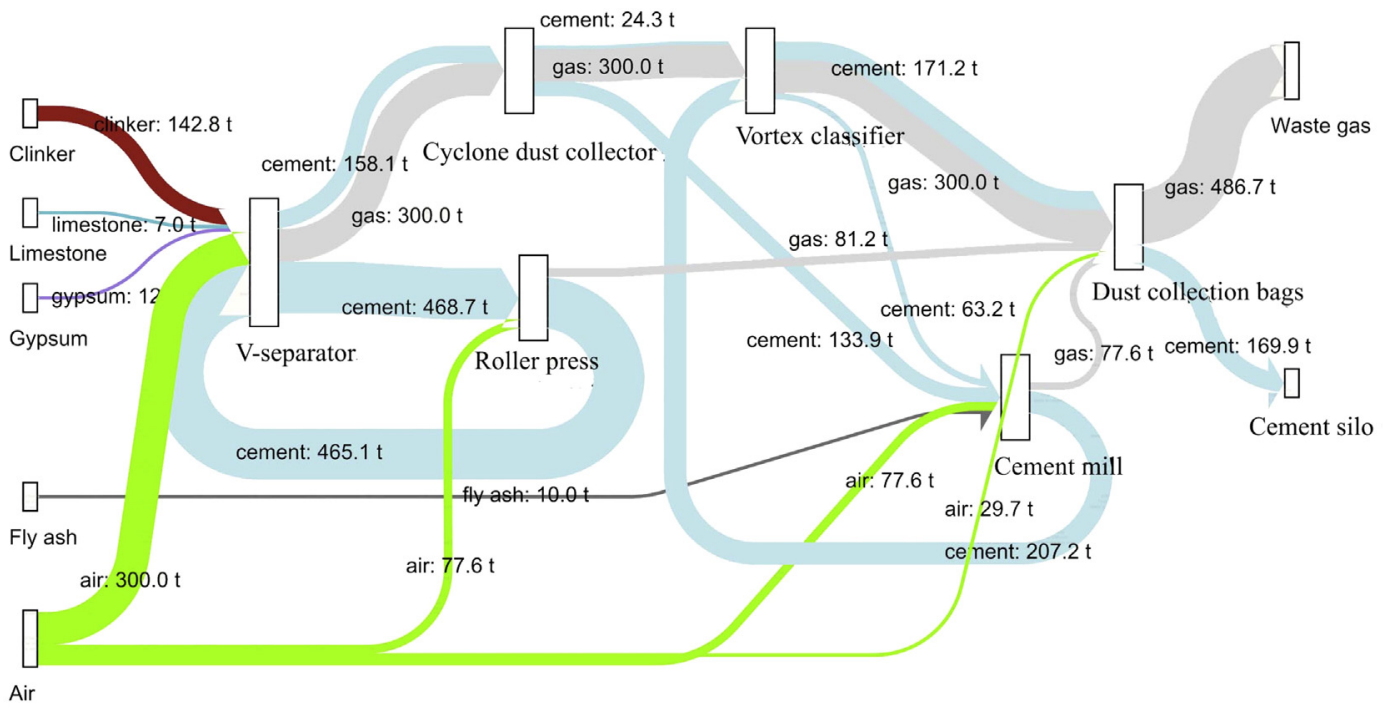

Fig. 10. Sankey diagram of cement grinding system.

of Air Pollutants for Cement Industry, the amount of particulate matter (PM) emissions from the machinery process cannot exceed $30 \mathrm{mg} / \mathrm{m}^{3}$ (MEPPRC, Ministry of Environmental Protection of the People's Republic of China, 2004). Thus, if the waste gas and heat are recycled, $290.28 \mathrm{MJ}$ of energy will be saved and PM emission will reduce by $63.43 \mathrm{~g}$ per ton of cement produced. Thus, an approach for recycling the low-temperature waste gas from grinding systems will be a potential topic of future research and development. If half of the waste gases discharged from the dust collector are recycled to replace the ambient air entered into the grinding system, the material efficiency in raw meal preparation and cement grinding will increase to $57.02 \%$ and $40.00 \%$, respectively. In this case, the PM emission will decrease to $15 \mathrm{mg} / \mathrm{t}$, and the reduction in PM emissions from China's cement industry will increase to $1.44 \mathrm{Mt} / \mathrm{a}$; 948 million Yuan could be saved by the entire industry.

Thus, it is clear that to generate fewer demands for natural resources, it is better to reduce waste in cement production lines. Regarding the waste produced, it should ideally be recycled to reduce the consumption of natural resources. The effectiveness of these measures has been demonstrated in the literature (Brunke and Blesl, 2014; Habert et al., 2010; Ishak and Hashim, 2014; Madlool et al., 2013; Mikulčić et al., 2015; Schneider et al., 2011; Woodward and Duffy, 2011). These studies comprehensively discussed various energy saving measures and their potential for reducing $\mathrm{CO}_{2}$ emissions from the manufacture of cement. The purpose of these papers were to demonstrate that a more energy efficient and sustainable cement production can be achieved by adopting material saving measures in the process of cement production. The adoption of resource conservation measures in an existing plant is essential, particularly in China, for 1) optimal use of resources in the cement industry, 2 ) use of industrial by-products and alternative fuels to replace cement natural resources and fossil fuels, 3) reduction of environmental pollution generated from industries. These measures will save natural resources and improve material efficiency and environmental friendliness of the cement industry.

\section{Conclusions}

The amount of natural materials currently available cannot meet the amount required for the large-scale production and consumption of cement; thus, reducing the use of natural resources is currently a key focus in the cement industry. Many studies have focused on the material and energy flow in steel, paper, and other industries; however, studies on the mass flows associated with the cement production process are fairly limited. Thus, the first material flow route for cement plants was examined in this study. Additionally, a cement plant was surveyed to quantify the amount of material consumed during the cement processing stages by using the mass calculation method discussed in section 3 . In the surveyed cement plant, three balances are established between input and output material in the raw mill, clinker production, and cement grinding system. $2.48 \mathrm{t}, 4.69 \mathrm{t}$, and $3.41 \mathrm{t}$ of materials are required to produce a ton of the product in raw material preparation, clinker production, and cement grinding stages; waste gases account for the largest proportion of the output, accounting for $58.41 \%, 75.03 \%$, and $70.33 \%$ of the total output in the three stages respectively. The high- and lowtemperature waste gases from the clinker cooler and pre-heater system are used for other purposes. However, these waste gases from raw meal and cement grinding system at a temperature of $353.15 \mathrm{~K}$ are directly discharged into the atmosphere. The recycle rate of waste gas discharged from the clinker production system is remarkably higher than that of the raw meal and cement grinding system. In the surveyed cement plant, $1.21 \mathrm{t}$ of limestone, $0.09 \mathrm{t}$ of silica, and $5.81 \mathrm{t}$ of air are required to produce one ton of cement (P.O.42.5); meanwhile, $4.79 \mathrm{t}$ of waste gas is discharged into the atmosphere and $1.62 \mathrm{t}$ of heat gas is used for drying raw materials and coal, and driving the steam turbine to generate electricity. Thus, it is clear that the recovery of energy and resources may be realized from waste gas and heat loss, and a conscious and planned effort is necessary to improve material utilization in the cement production process, particularly in the raw meal and cement mill units. This important information can be used to aid the development of industry policies related to the goal of achieving sustainable development in the cement industry and minimizing the negative environmental impact from cement production, resource usage, and waste emissions.

Because of limited available data, there are some deficiencies in the findings of this study. Firstly, we only investigate the material efficiency at the typical cement plant; the industrial efficiency should be assessed with further empirical study, as the methods and models adopted in this paper are exploratory and 


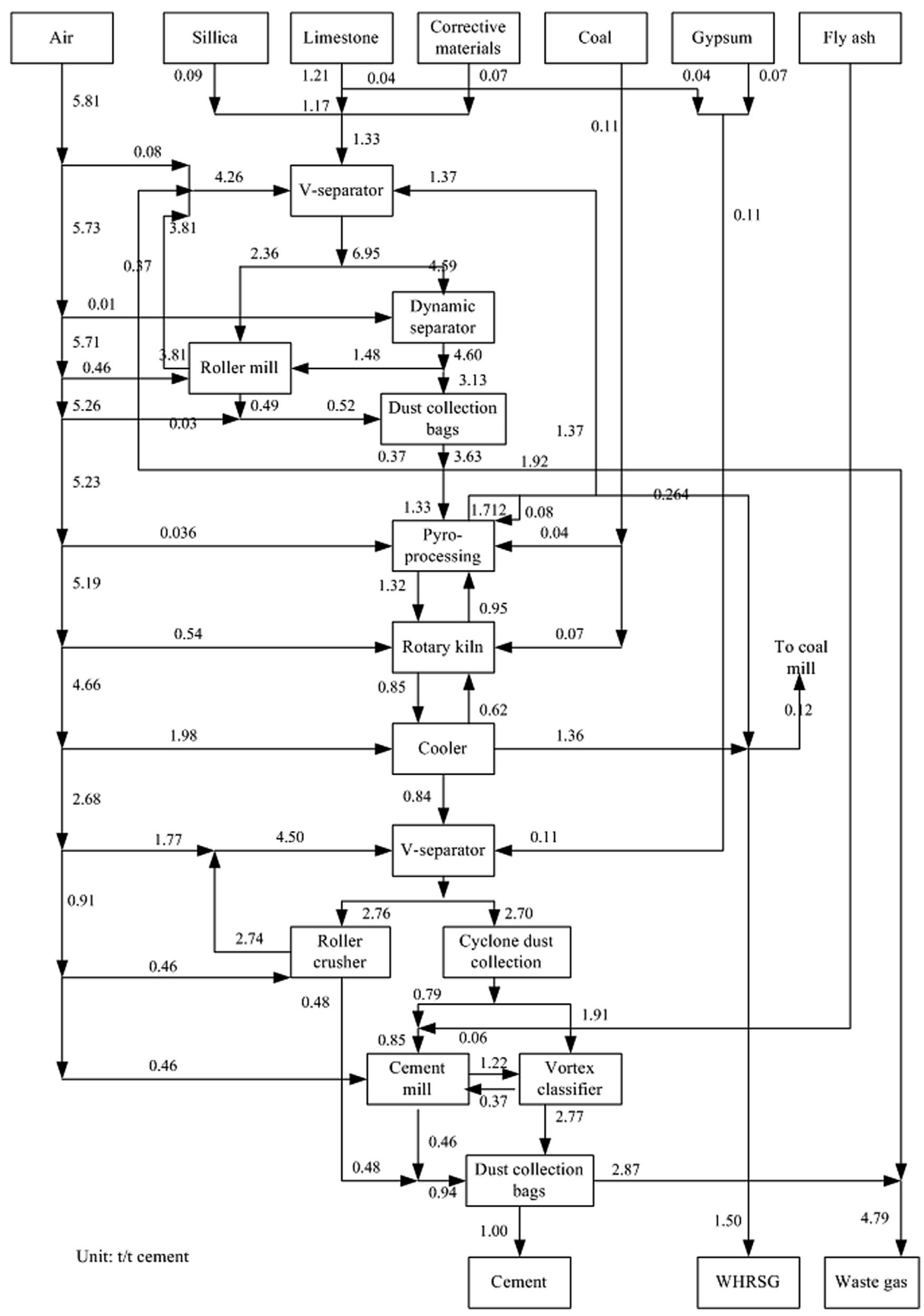

Fig. 11. Materials flow profile of for the investigated cement plant.

experimental. Secondly, in this study, we have made an assumption in the analysis of recycling low-temperature waste gas, and the availability of practical data of better quality would allow a more accurate analysis. It is also important that research be undertaken for greater understanding of how recycling the low-temperature waste gas in various applications would affect the environment and cost inventories. If these analyses are included, the results of the current study may vary extensively. 


\section{Acknowledgments}

This work was financially supported by the Strategic Priority Research Program -Climate Change: Carbon Budget and Related Issues of the Chinese Academy of Sciences (Grant No. XDA05010400), China Postdoctoral Science Foundation (No. 2015T80125, and No. 2014M550819), and the National Natural Science Foundation of China (No. 41501590). The authors thank the anonymous reviewers for their valuable comments and suggestions.

\section{Appendix A. Supplementary data}

Supplementary data related to this article can be found at http:// dx.doi.org/10.1016/j.jclepro.2015.08.054.

\section{References}

Andersen, J.P., Hyman, B., 2001. Energy and material flow models for the US stee industry. Energy 26, 137-159.

Atmaca, A., Yumrutaș, R., 2014. Thermodynamic and exergoeconomic analysis of cement plant: part II - application. Energy Convers. Manag. 79, 799-808.

Baeza-Brotons, F., Garcés, P., Payá, J., Saval, J.M., 2014. Portland cement systems with addition of sewage sludge ash. Application in concretes for the manufacture of blocks. J. Clean. Prod. 82, 112-124.

Benhelal, E., Zahedi, G., Shamsaei, E., Bahadori, A., 2013. Global strategies and potentials to curb $\mathrm{CO}_{2}$ emissions in cement industry. J. Clean. Prod. 51, 142-161.

Brown, H.L., 1996. Energy Analysis of 108 Industrial Processes. The Fairmont Press, Inc., Lilburn, Georgia.

Brunke, J.-C., Blesl, M., 2014. Energy conservation measures for the German cement industry and their ability to compensate for rising energy-related production costs. J. Clean. Prod. 82, 94-111.

CCA, China Cement Association, 2012. China Cement Almanac 2011. China Building Materials Press, Beijing, China.

Chen, W., Hong, J., Xu, C., 2014. Pollutants generated by cement production in China, their impacts, and the potential for environmental improvement. J. Clean. Prod. http://dx.doi.org/10.1016/j.jclepro.2014.1004.1048.

Elchalakani, M., Aly, T., Abu-Aisheh, E., 2014. Sustainable concrete with high volume GGBFS to build Masdar city in the UAE. Case Stud. Constr. Mater. 1, 10-24.

Gao, T., 2013. Resource Consumption and Carbon Dioxide Emissions in the Process of Cement Production. Institute of Geographic Science and Natural Resource Research, C.A.S. University of Chinese Academy of Sciences, Beijing, China.

Gao, T., Shen, L., Shen, M., Chen, F., Liu, L., Gao, L., 2014. Analysis on differences of carbon dioxide emission from cement production and their major determinants. J. Clean. Prod. http://dx.doi.org/10.1016/j.jclepro.2014.1011.1026.

Habert, G., Billard, C., Rossi, P., Chen, C., Roussel, N., 2010. Cement production technology improvement compared to factor 4 objectives. Cem. Concr. Res. 40, 820-826.

Hong, G.-B., Ma, C.-M., Chen, H.-W., Chuang, K.-J., Chang, C.-T., Su, T.-L., 2011. Energy flow analysis in pulp and paper industry. Energy 36, 3063-3068.

Iacobescu, R.I., Koumpouri, D., Pontikes, Y., Saban, R., Angelopoulos, G., 2011. Valorisation of electric arc furnace steel slag as raw material for low energy belite cements. J. Hazard. Mater. 196, 287-294.

Ishak, S.A., Hashim, H., 2014. Low carbon measures for cement plant - a review. J. Clean. Prod. http://dx.doi.org/10.1016/j.jclepro.2014.1011.1003.

Kapur, A., van Oss, H.G., Keoleian, G., Kesler, S.E., Kendall, A., 2009. The contemporary cement cycle of the United States. J. Mater. Cycles Waste Manag. 11, 155-165.

Karstensen, K.H., 2006. Cement Production in Vertical Shaft Kilns in China: Status and Opportunities for Improvement. Report to the United Nations Industrial Development Organization, Vienna, Austria.
Li, C., Nie, Z., Cui, S., Gong, X., Wang, Z., Meng, X., 2014a. The life cycle inventory study of cement manufacture in China. J. Clean. Prod. 72, 204-211.

Li, H., Xu, W., Yang, X., Wu, J., 2014b. Preparation of Portland cement with sugar filter mud as lime-based raw material. J. Clean. Prod. 66, 107-112.

Low, M.-S., 2005. Material Flow Analysis of Concrete in the United States. Massachusetts Institute of Technology, Massachusetts, U.S.A.

Madlool, N., Saidur, R., Hossain, M., Rahim, N., 2011. A critical review on energy use and savings in the cement industries. Renew. Sustain. Energy Rev. 15, 2042-2060.

Madlool, N., Saidur, R., Rahim, N., Kamalisarvestani, M., 2013. An overview of energy savings measures for cement industries. Renew. Sustain. Energy Rev. 19, 18-29.

MEPPRC, Ministry of Environmental Protection of the People's Republic of China, 2004. Emission Standard of Air Pollutants for Cement Industry. China Environment Press, Beijing, China.

Michaelis, P., Jackson, T., 2000. Material and energy flow through the UK iron and steel sector. Part 1: 1954-1994. Resour. Conserv. Recycl. 29, 131-156.

Mikulčić, H., Vujanović, M., Duić, N., 2015. Improving the sustainability of cement production by using numerical simulation of limestone thermal degradation and pulverized coal combustion in a cement calciner. J. Clean. Prod. 88, $262-271$.

NBSC, National Bureau of Statistics of China, 2012. China statistical Yearbook 2011. China Statistical Press, Beijing,China.

Oh, D.-Y., Noguchi, T., Kitagaki, R., Park, W.-J., 2014. CO 2 emission reduction by reuse of building material waste in the Japanese cement industry. Renew. Sustain. Energy Rev. 38, 796-810.

Ozalp, N., Hyman, B., 2007. Allocation of energy inputs among the end-uses in the US petroleum and coal products industry. Energy 32, 1460-1470.

Pardo, N., Moya, J.A., Mercier, A., 2011. Prospective on the energy efficiency and $\mathrm{CO}_{2}$ emissions in the EU cement industry. Energy 36, 3244-3254.

Roskos, C., Cross, D., Berry, M., Stephens, J., 2011. Identification and verification of self-cementing fly ash binders for "Green" concrete. In: Proceedings of the 2011 World of Coal Ash (WOCA) Conference-May, 9-12 in Denver CO, USA.

Sakai, K., 2009. Towards environmental revolution in concrete technologies. In: Proceedings of the International fib Symposium. Concrete: 21st Century Superhero. London, UK.

Schneider, M., Romer, M., Tschudin, M., Bolio, H., 2011. Sustainable cement production-present and future. Cem. Concr. Res. 41, 642-650.

Shu, X., Huang, B., 2014. Recycling of waste tire rubber in asphalt and portland cement concrete: an overview. Constr. Build. Mater. 67, 217-224.

Smith, R., Kersey, J., Griffiths, P.J., 2002. The Construction Industry Mass Balance: Resource Use, Wastes and Emissions. Viridis Report VR4, UK.

Sogut, M., Oktay, Z., Hepbasli, A., 2009. Energetic and exergetic assessment of a trass mill process in a cement plant. Energy Convers. Manag. 50, 2316-2323.

Sun, W.-q., Cai, J.-j., 2009. Material Flow, Energy Flow and Energy Flow Network in Iron and Steel Enterprise. Intech. http://cdn.intechopen.com/pdfs-wm/37116. pdf.

Tang, J.Q., 2010. Status of low temperature cogeneration technology in dry rotary cement kilns of China. China Cem. 56-58.

U.S.G.S., U.S. Geological Survey, 2014. Mineral commodity Summaries 2013. http:// minerals.usgs.gov/minerals/pubs/mcs/.

Uwasu, M., Hara, K., Yabar, H., 2014. World cement production and environmental implications. Environ. Dev. 10, 36-47.

Wang, M., Lee, H., Molburg, J., 2004. Allocation of energy use in petroleum refineries to petroleum products. Int. J. Life Cycle Assess. 9, 34-44.

Woodward, R., Duffy, N., 2011. Cement and concrete flow analysis in a rapidly expanding economy: Ireland as a case study. Resour. Conserv. Recycl. 55, $448-455$.

Worrell, E., Phylipsen, D., Einstein, D., Martin, N., 2000. Energy Use and Energy Intensity of the US Chemical Industry. Lawrence Berkeley National Laboratory, Berkeley, CA , U.S.A.

Worrell, E., Price, L., Martin, N., Hendriks, C., Meida, L.O., 2001. Carbon dioxide emissions from the global cement industry 1. Annu. Rev. Energy Environ. 26, 303-329. 